\title{
Article
}

\section{Light rare earth element redistribution during hydrothermal alteration at the Okorusu carbonatite complex, Namibia}

\author{
Delia Cangelosi ${ }^{\star \star}$ (D), Sam Broom-Fendley², David Banks${ }^{1}$, Daniel Morgan ${ }^{1}$ and Bruce Yardley ${ }^{1}$ \\ ${ }^{1}$ School of Earth and Environment, University of Leeds, Leeds LS2 9JT, UK; and ${ }^{2}$ Camborne School of Mines, University of Exeter, Penryn Campus, \\ Cornwall TR10 9FE, UK
}

\begin{abstract}
The Cretaceous Okorusu carbonatite, Namibia, includes diopside-bearing and pegmatitic calcite carbonatites, both exhibiting hydrothermally altered mineral assemblages. In unaltered carbonatite, $\mathrm{Sr}, \mathrm{Ba}$ and rare earth elements $(R E E)$ are hosted principally by calcite and fluorapatite. However, in hydrothermally altered carbonatites, small $(<50 \mu \mathrm{m})$ parisite- $(\mathrm{Ce})$ grains are the dominant $R E E$ host, while Ba and $\mathrm{Sr}$ are hosted in baryte, celestine, strontianite and witherite. Hydrothermal calcite has a much lower trace-element content than the original, magmatic calcite. Regardless of the low REE contents of the hydrothermal calcite, the REE patterns are similar to those of parisite-(Ce), magmatic minerals and mafic rocks associated with the carbonatites. These similarities suggest that hydrothermal alteration remobilised REE from magmatic minerals, predominantly calcite, without significant fractionation or addition from an external source. Barium and Sr released during alteration were mainly reprecipitated as sulfates. The breakdown of magmatic pyrite into iron hydroxide is inferred to be the main source of sulfate. The behaviour of sulfur suggests that the hydrothermal fluid was somewhat oxidising and it may have been part of a geothermal circulation system. Late hydrothermal massive fluorite replaced the calcite carbonatites at Okorusu and resulted in extensive chemical change, suggesting continued magmatic contributions to the fluid system.
\end{abstract}

Keywords: rare earth element, carbonatite, hydrothermal transport, Okorusu

(Received 7 May 2019; accepted 10 August 2019; Accepted Manuscript published online: 15 August 2019; Associate Editor: Aniket Chakrabarty)

\section{Introduction}

The rare earth elements (REE) are well known as 'critical metals' metals which are sourced from restricted regions and have low substitutability and recyclability (Wall, 2014; European Commission, 2017; US Geological Survey, 2018). The largest and highest-grade REE deposits are associated with carbonatite complexes (Chakhmouradian and Wall, 2012; Chakhmouradian and Zaitsev, 2012; Wall, 2014; Verplanck et al., 2016). While this association demonstrates that magmatic processes are required for $R E E$ concentration, the REE as a group are also mobile in some hydrothermal fluids (Linnen et al., 2014), and hydrothermal activity can play a major role in the development of economic concentrations of REE (e.g. Smith et al., 2000, 2016).

A number of hydrothermally modified REE deposits have been recognised in a range of geological environments (e.g. Alderton et al., 1980; Lewis et al., 1998; Gysi and Williams-Jones, 2013). Indeed, the type-locality for several REE minerals, Bastnäs, is a skarn deposit (Holtstam and Andersson, 2007; Holtstam et al., 2014). Many carbonatites show evidence of hydrothermal reworking,

\footnotetext{
${ }^{*}$ Author for correspondence: Delia Cangelosi, Email: ee12dac@leeds.ac.uk This paper is part of a thematic set arising from the 3rd International Critical Metals Conference (Edinburgh, May 2019).

Cite this article: Cangelosi D., Broom-Fendley S., Banks D., Morgan D. and Yardley B. (2020) Light rare earth element redistribution during hydrothermal alteration at the Okorusu carbonatite complex, Namibia. Mineralogical Magazine 84, 49-64. https:// doi.org/10.1180/mgm.2019.54
}

which may be extensive (e.g. Wall et al., 2008; Moore et al., 2015; Broom-Fendley et al., 2017a).

Evidence for hydrothermal mobility of $R E E$ comes from both experimental and natural studies of REE deposits (Perry and Gysi, 2018). Experimental studies indicate the solubility of $R E E$ is determined mainly by temperature and ligand availability (Williams-Jones et al., 2012). The stability of REE aqueous complexes with most ligands decreases along the lanthanide series, with light (L)REE (La to $\mathrm{Sm}$ ) complexes more stable than the heavy (H)REE (Migdisov et al., 2016). Complexation by sulfate is the exception, with all $R E E$-sulfate complexes having a similar stability (Migdisov and Williams-Jones, 2008). In most geological settings, the REE are believed to be transported predominantly as $\mathrm{Cl}^{-}$complexes, reflecting the dominance of $\mathrm{Cl}^{-}$over other potential ligands in most natural fluids (Banks et al., 1994), as well as the greater solubility of REE-chloride complexes relative to fluoride, phosphate and carbonate complexes (Williams-Jones et al., 2012).

Not all carbonatites show evidence of secondary fluid reworking. The REE can be hosted in apatite, a common carbonatite magmatic mineral for which the REE have a strong affinity (e.g. Giebel et al., 2017). Apatite in carbonatites commonly contains over 1 wt.\% total REE (Bühn et al., 2003; Broom-Fendley et al., 2016; Chakhmouradian et al., 2017). REE may also be hosted in burbankite $\left[(\mathrm{Na}, \mathrm{Ca})_{3}(\mathrm{Sr}, \mathrm{Ca}, \mathrm{REE}, \mathrm{Ba})_{3}\left(\mathrm{CO}_{3}\right)_{5}\right]$ which typically forms in a magmatic environment or close to the magmatic-hydrothermal transition (Zaitsev et al., 1998, 2002; Moore et al., 2015; 
Broom-Fendley et al., 2017b). Wall (2014) however, noted that in carbonatite-related deposits, economic levels of REE are contained mainly in secondary minerals such as $R E E$ fluorcarbonates and monazite. The two main mechanisms which may determine the economic viability of a carbonatite deposit for the $R E E$ are thus primary enrichment at the magmatic stage, which is controlled predominantly by apatite crystallisation, and secondary hydrothermal reworking.

In this study we investigate the mineralogy of the Okorusu Carbonatite Complex, Namibia, in order to understand the mechanism and scale of hydrothermal reworking of REE in a carbonatite. Although Okorusu is not a REE-rich carbonatite, the relatively small-scale alteration where $R E E$ contents are locally upgraded, provides an opportunity to understand the key processes. We report on how the REE are mobilised and concentrated from the magmatic to the late hydrothermal stages and investigate whether the locally elevated bulk-REE contents are due to secondary enrichment from an external source or redistribution from nearby parts of the complex.

\section{The Okorusu carbonatite complex}

The Okorusu carbonatite complex is part of the Cretaceous Damaraland Igneous Province $(\sim 137$ to $124 \mathrm{Ma})$, which is thought to be related to the Tristan da Cunha hot spot and the opening of the South Atlantic (Milner et al., 1995). Okorusu has a radiometric age of $126.6 \pm 7.3 \mathrm{Ma}$ (Milner et al., 1995). The province consists of several intrusions of alkaline rocks and carbonatites trending northeast from the Cape Cross complex at the Atlantic coast (Fig. 1). Okorusu is the most north-easterly of this chain of intrusions and is located $\sim 45 \mathrm{~km} \mathrm{NNE}$ of the town of Otjiwarongo $\left(20^{\circ} 2^{\prime} 46.45^{\prime \prime} \mathrm{S}, 16^{\circ} 44^{\prime} 32.90^{\prime \prime} \mathrm{E}\right)$.

The detailed geological mapping by Van Zijl (1962) shows that it comprises a ring complex $\sim 5 \mathrm{~km}$ by $6 \mathrm{~km}$, consisting of syenite, nepheline syenite and carbonatite with an associated fenite aureole and hydrothermal fluorite mineralisation (Fig. 2). The country rocks adjacent to the complex are intruded by mafic dykes (Table 1), which are themselves intruded by calcite carbonatite. The mafic dykes may be an early phase of the intruding igneous suite (Fig. 2). The main carbonatite bodies are medium grained $(0.25 \mathrm{~mm}$ to $2 \mathrm{~mm})$ calcite carbonatites with white/grey calcite and accessory apatite and feldspar (Van Zijl, 1962; Bühn et al., 2002). Shivdasan (2002) described two additional types of carbonatite: clinopyroxene carbonatite (diopside-bearing calcite carbonatite in this study), which has a silica content ranging from 9 wt. $\%$ to 12 wt.\% and on average contains $~ 15$ vol.\% pyroxene, and subordinate pegmatite carbonatite (pegmatitic calcite carbonatite in this study), characterised by a very coarse grain size (from $2 \mathrm{~cm}$ to $>20 \mathrm{~cm}$ ), occurring as local pods or segregations within the diopside-bearing carbonatite.

The country rocks around the complex are regionally metamorphosed sediments of the Pan-African Damara system, comprising schist, marble, conglomerate and quartzite. Greywacke close to the carbonatites is locally fenitised to an alkali clinopyroxene-rich rock referred to as alkaline pyroxenite by Van Zijl (1962). The fenites themselves were subsequently altered by later hydrothermal activity, as demonstrated by fractures containing hydrothermal minerals including fluorite, alkali feldspar, magnetite, pyrite, apatite, quartz and calcite (Van Zijl, 1962).

For two decades, Okorusu was mined to extract fluorite for the production of HF; currently the mine is in care and maintenance. Fluorite mineralisation occurs in the high-grade fenite aureole in contact with Damara marbles, in calc-silicate lithologies, and in schists (Bühn et al., 2002). Fluorite ore typically forms massive replacement textures. Other hydrothermal events occurred prior to fluorite deposition: magnetite and pyrrhotite hosted in the diopside-bearing carbonatite are hydrothermally altered with marcasite or hematite replacing pyrite and later magnetite (Shivdasan, 2002). Hydrothermal alteration of the calcite carbonatite led to the introduction of euhedral quartz veins and growth of secondary minerals including synchysite [CaLREE $\left.\left(\mathrm{CO}_{3}\right)_{2} \mathrm{~F}\right]$, baryte and fluorite (Shivdasan, 2002).

This study is based on detailed examination of two diopsidebearing calcite carbonatite pods (e.g. Fig. $3 a$ ), a pegmatitic calcite carbonatite pod $\sim 11 \mathrm{~m}$ wide and $4 \mathrm{~m}$ high (Fig. $3 b$ ), a mafic dyke (sample OKC4) and a fluorite body (Fig. 2). Cerium is the dominant lanthanide in all the REE minerals identified at Okorusu; hence, the suffix -(Ce) will be omitted from mineral names for simplicity.

\section{Methodology}

Samples were collected from the Okorusu Fluorite mine in October 2015. The mine comprises several pits (outlined in Fig. 2), which display differences in fluorite grade, grain size, colour and mineral associations. For the purposes of this study, which focusses on hydrothermal alteration in the carbonatites, these differences in the nature of the fluorite ore are of secondary importance. Samples collected from Pits A and C are labelled as OKA and OKC, respectively (Fig. 3).

Mineral paragenetic relationships were established using optical petrography of thin sections and corresponding doubly polished wafers together with scanning electron microscopy (SEM), back scattered electron (BSE) and SEM-cathodoluminescence (SEM-CL) imaging carried out at the University of Leeds using a FEI Quanta 650 Field Emission Gun Scanning Electron Microscope operated at $20 \mathrm{kV}$.

Mineral compositions were determined with a JEOL JXA8230 Electron Microprobe (EMPA) at the University of Leeds. Beam conditions for calcite were: $15 \mu \mathrm{m}$ spot, $15 \mathrm{kV}$ and $3 \mathrm{nA}$; apatite and fluorite: $10 \mu \mathrm{m}, 15 \mathrm{kV}$ and $8 \mathrm{nA}$; and diopside: $1 \mu \mathrm{m}, 20 \mathrm{kV}$ and $30 \mathrm{nA}$. The standards and element lists used for the different minerals are summarised in Appendix 1 (Supplementary material see below) alongside the detection limit and on-peak and off-peak counting times for each element. Slight fluctuations in detection limits reflect the individual background measurement for each analysis. The standards were chosen to match the structure of the unknown as closely as possible, using available material. Data reduction was with the Phi-Rho-Z Armstrong matrix correction (Packwood and Brown, 1981).

Complementary trace-element data for the minerals were obtained by laser ablation inductively coupled plasma mass spectrometry (LA-ICP-MS) using a $193 \mathrm{~nm}$ ArF Excimer laser coupled to an Agilent 7500 c ICP-MS instrument at the University of Leeds. Analyses were performed using a spot size from 25 to $51 \mu \mathrm{m}$, a $10 \mathrm{~J} \mathrm{~cm}^{-2}$ laser fluence and a repetition rate of $5 \mathrm{~Hz}$. The analyses were run in reaction cell mode using $2.5 \mathrm{ml} \mathrm{min}{ }^{-1} \mathrm{H}_{2}$ to supress ${ }^{40} \mathrm{Ar}^{+}$and ${ }^{40} \mathrm{Ar}^{16} \mathrm{O}^{+}$interferences on ${ }^{40} \mathrm{Ca}^{+}$and ${ }^{56} \mathrm{Fe}^{+}$and improve the measurement of ${ }^{39} \mathrm{~K}$ by removing the small interferences from ${ }^{39} \mathrm{Ar}$. The following isotopes were analysed: ${ }^{23} \mathrm{Na},{ }^{24} \mathrm{Mg},{ }^{29} \mathrm{Si},{ }^{39} \mathrm{~K},{ }^{40} \mathrm{Ca},{ }^{47} \mathrm{Ti},{ }^{55} \mathrm{Mn},{ }^{56} \mathrm{Fe},{ }^{88} \mathrm{Sr},{ }^{89} \mathrm{Y}$, ${ }^{238} \mathrm{Th},{ }^{232} \mathrm{U}{ }^{137} \mathrm{Ba},{ }^{139} \mathrm{La},{ }^{140} \mathrm{Ce},{ }^{141} \mathrm{Pr},{ }^{146} \mathrm{Nd},{ }^{147} \mathrm{Sm},{ }^{153} \mathrm{Eu}$, ${ }^{157} \mathrm{Gd},{ }^{159} \mathrm{~Tb},{ }^{163} \mathrm{Dy},{ }^{165} \mathrm{Ho},{ }^{166} \mathrm{Er},{ }^{169} \mathrm{Tm},{ }^{172} \mathrm{Yb}$ and ${ }^{175} \mathrm{Lu}$. The element lists used per run alongside the limit of detection for each element are summarised in Appendix 1. The instrument 


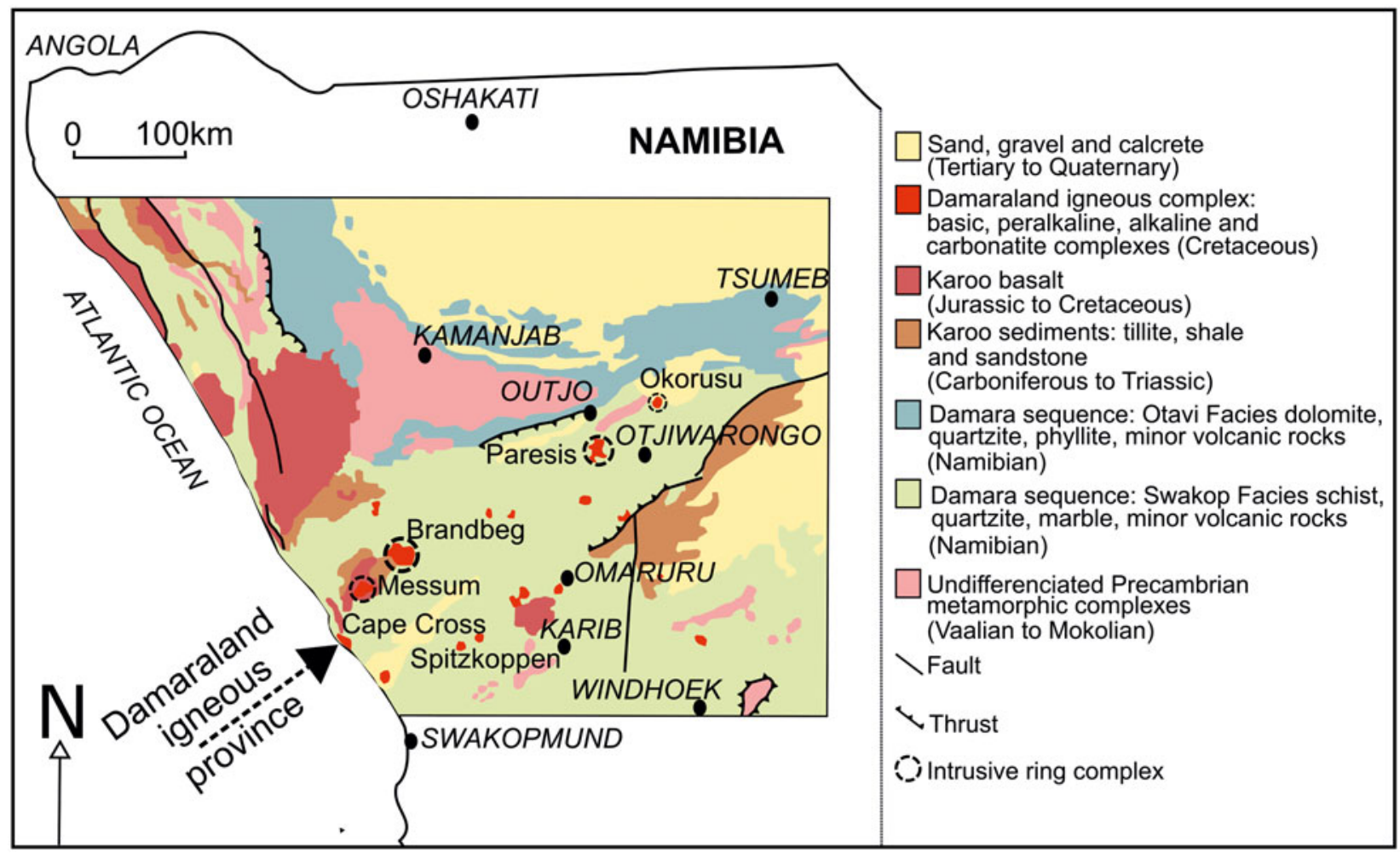

Fig. 1. Simplified geological map of Namibia showing the Damaraland igneous province trending North-East (after the geological map of Namibia, from Schreiber et al., 1977).

was calibrated using NIST610 and NIST612 silicate glass standards, and these were ablated six times each at the beginning and end of each analysis session to monitor instrument drift, which was found to be insignificant. Because the LA-ICP-MS yields wt/wt ratios, the value of $\mathrm{Ca}$ (for carbonates, apatite and fluorite) or $\mathrm{Si}$ (for silicate minerals) was determined by EMPA in order to quantify the other elements analysed by LA-ICP-MS. Where this was not possible at a particular spot, the median concentrations of $\mathrm{Ca}$ or $\mathrm{Si}$ determined in nearby areas were used. For parisite $\left[\mathrm{Ca}(L R E E)_{2}\left(\mathrm{CO}_{3}\right)_{3} \mathrm{~F}_{2}\right]$, the stoichiometric Ca content was used to normalise analyses, as it was not analysed by EMPA. The ablation locations in each sample were the same as the locations of previous EMPA analyses.

Bulk-rock analyses were undertaken by Activation Laboratories Ltd. with the sample preparation undertaken at the University of Leeds. Samples were powdered using a steel pestle and mortar and an agate TEMA barrel, and sieved to $<200 \mu \mathrm{m}$. The methods 4 Litho and 4F-ISE were used on the calcite carbonatite and mafic dyke samples and the method 4Litho was used for the fluorite ore samples. The methods and detection limits are detailed in Appendix 2.

\section{Field relationships and mineral paragenesis}

Diopside-bearing and pegmatitic calcite carbonatites are the two main carbonatite types sampled for this study (Table 1). They record evidence of both magmatic crystallisation of the carbonatite magma and subsequent hydrothermal activity which led to the development of the present REE minerals. The mineralogy of the samples investigated is detailed in Table 1 and outlined below.
Diopside-bearing calcite carbonatites locally intrude marble country rock, and where this occurs they exhibit a magnetite aureole (Fig. 3a). Sample OKA5 is referred to as 'least altered diopside-bearing calcite carbonatite' owing to its high percentage of magmatic minerals. 'Altered, diopside-bearing calcite carbonatite' (sample OKA1, Fig. 3A) is a diopside-bearing calcite carbonatite which has undergone partial replacement of magmatic minerals by hydrothermal phases.

Pegmatitic calcite carbonatites occur as small pods within diopside-bearing calcite carbonatite, cementing brecciated diopside-bearing calcite carbonatite and in contact with fenite (Hagni and Shivdasan, 2001; Shivdasan, 2002), making it the last carbonatite type to form. Four samples and sub-samples are from a pegmatitic calcite carbonatite pod (Fig. $3 b$ ). The highly altered margins of this pod comprise $\sim 95 \%$ of hydrothermal minerals (sample OKC19-2) and is referred to as intensely altered calcite carbonatite' in the rest of this study (Fig. $3 b$ ). The degree of alteration is less intense in the interior of the pod.

Four phases of mineral growth have been identified: magmatic (stage 1), late magmatic (stage 2), hydrothermal (stage 3 ) and late hydrothermal fluorite mineralisation (stage 4 ). The textural relationships that determine the sequence of mineral growth are illustrated in Figs 4 and 5, while the mineral paragenesis is summarised in Fig. 6.

\section{Stage 1 and 2 - Magmatic to late magmatic minerals in the calcite carbonatites}

The Okorusu calcite carbonatites predominantly exhibit magmatic textures typical of carbonatites (Chakhmouradian et al., 2016). Magmatic calcite occurs as very large $(0.5 \mathrm{~cm}$ to $>7 \mathrm{~cm})$ 


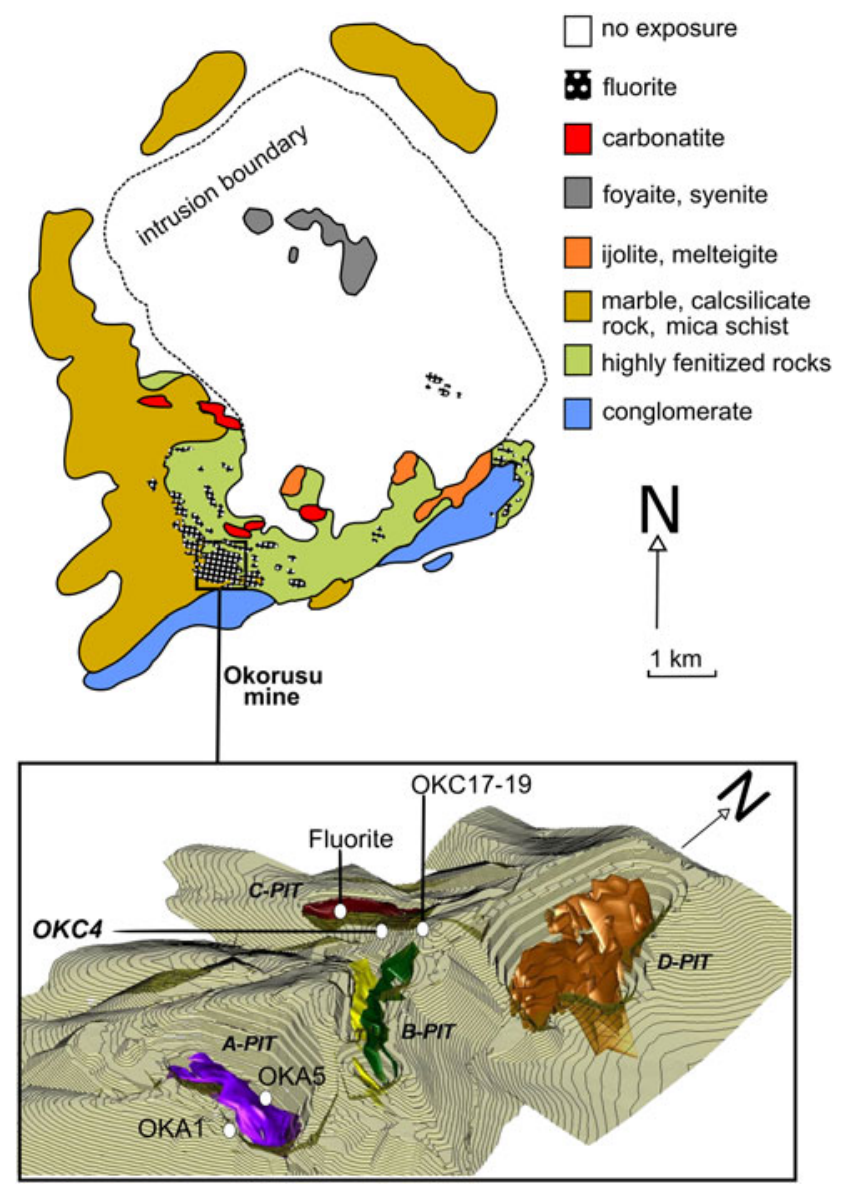

Fig. 2. Simplified geology of the Okorusu carbonatite complex (after Van Zijl, 1962) with a 3D model of the Okorusu fluorite mine and the locations of samples used in this study (the fluorite ore bodies are represented in different colours only to differentiate fluorite in different pits) (Okorusu Fluorspar, 2014, pers. comm.).

twinned crystals and makes up the bulk of all carbonatite types. Magmatic calcite is distinguished from stage 3 hydrothermal calcite because it appears brighter in BSE images due to its higher level of Sr (Fig. 4b,d), and does not contain inclusions of baryte, strontianite or other sulfates or carbonates.

Clinopyroxenes in the diopside-bearing calcite carbonatite are diopside and occur as clusters of subhedral to euhedral crystals. Euhedral grains commonly display growth zoning while zoning in subhedral grains is less regular (Fig. $4 a, b$ ). Diopside commonly exhibits resorption along its edges, and occurs in two forms: evenly distributed through the least altered diopside-bearing calcite carbonatite (Fig. $4 a, b$ ) or segregated as diopside-rich clusters in the altered diopside-bearing calcite carbonatite. Diopside inclusions with resorbed edges occur in magmatic apatite and calcite suggesting that diopside was early to crystallise from the carbonatite magma (Fig. 6).

Apatite is the most significant magmatic REE-bearing mineral in the Okorusu calcite carbonatites. Stage 1 and 2 apatite occurs as medium-grained subhedral crystals (Fig. $4 a, e$ ), locally radiating in clusters within apatite-rich zones typical of the diopsidebearing calcite carbonatite, but also as individual grains in contact with calcite (Fig. 4d), as inclusions in Ti-bearing magnetite (Fig. 4e) and Nb-bearing phases, or as vein-like clusters in the pegmatitic calcite carbonatite. The grains consistently exhibit similar textures, including complex zoning (Fig. 4b,m,o), with
SEM-CL imaging revealing a pill-like shape typical of plutonic carbonatite (Chakhmouradian et al., 2017, their fig. 5b), calcite inclusions (Fig. 4b,c). Magmatic apatites host inclusions of magmatic calcite and vice versa, indicating these minerals are cogenetic (Fig. 6).

Apatite records a complex growth history revealed by SEM-CL imaging. Some oscillatory growth zoning is present (Fig. $4 m-o$ ) and the apatite SEM-CL patterns indicate that dissolution was interspersed with periods of growth (Fig. 4m,o). Dissolution made stage 1 apatite (dull CL) porous, and the pores were then infilled with stage 2 apatite (bright $\mathrm{CL}$ ) which truncates stage 1 zoning (Fig. 4m,o).

Similar textures in fluorapatite have been generated in hydrothermal experiments and have been ascribed to simultaneous dissolution-reprecipitation which creates porosity allowing enhanced transport and new growth (Harlov et al., 2003; Harlov et al., 2005). Harlov et al. (2005) describe topotaxial replacement of $R E E$-bearing fluorapatite by a $R E E$-depleted fluorapatite triggered by dissolution-reprecipitation in a $\mathrm{HCl}-\mathrm{H}_{2} \mathrm{SO}_{4}$ solution. Chakhmouradian et al. (2017) also describe a very similar dissolution-reprecipitation texture in magmatic apatite, interpreted as apatite re-equilibration with a fluid. The Okorusu stage 1 and 2 apatites similarly have uniform extinction. Stage 2 growth is a $3 \mathrm{D}$ process, which creates the irregular patches observed in SEM-CL imaging (Fig. 4m,o). SEM-CL patterns show that stage 1-stage 2 apatite relationships are consistent across the sample suites, irrespective of later alteration.

A few parisite crystals have developed on the edges of some magmatic apatites where it appears that part of the apatite was dissolved to crystallise parisite (Harlov et al., 2003, 2005) (Fig. 4n). Stage 2 apatite therefore has a cogenetic parisite generation.

Stage 2 apatite dissolution-reprecipitation might be driven by fluid exsolved from the crystallising carbonatite (Feng et al., 2016) or be post magmatic. While evidently formed after almost all the magmatic minerals, stage 2 apatite can occur enclosed entirely in magmatic calcite, with no post-magmatic hydrothermal calcite nearby, especially in the least altered calcite carbonatite (Fig. $4 o, p$ ). The lack of any later modification of adjacent magmatic calcite suggests that stage 2 apatite formed at the final magmatic stage while magmatic calcite was still stable. Both stage 1 and 2 apatites are replaced during later stage 3 hydrothermal alteration (Fig. $4 e, l$ ). In view of these observations, we believe that stage 2 apatite growth (and the associated parisite, Fig. 4n) did not form during the later stage 3 hydrothermal event.

Additional magmatic phases in the calcite carbonatites include phlogopite (which may host apatite and diopside inclusions), pyrite, which occurs as medium sized $(\sim 400 \mu \mathrm{m})$ subhedral crystals with apatite inclusions in sample OKA5 $(<5 \%$, Fig. $4 g)$ and Ti-bearing magnetite. A few crystals of an extensively altered euhedral Nb-bearing mineral with oscillatory zoning were also observed in the pegmatitic calcite carbonatite. The centres of the Nb-bearing crystals are porous, although $\mathrm{Nb}$ is present throughout the grain. The least altered parts give an energy dispersive spectrum dominated by $\mathrm{Nb}$ with associated peaks for $\mathrm{Sr}$, $\mathrm{Ti}, \mathrm{Ca}, \mathrm{Th}$ and Fe.

The association of calcite, apatite and iron oxide is typical of carbonatites (Le Bas and Srivastava, 1989; Kapustin, 1980; Chakhmouradian et al., 2016). On the basis of textures such as those illustrated in Fig. 4, we infer that the sequence of crystallisation was diopside joined by calcite, apatite and finally phlogopite (Fig. 6) (c.f. Weidendorfer et al., 2017). 

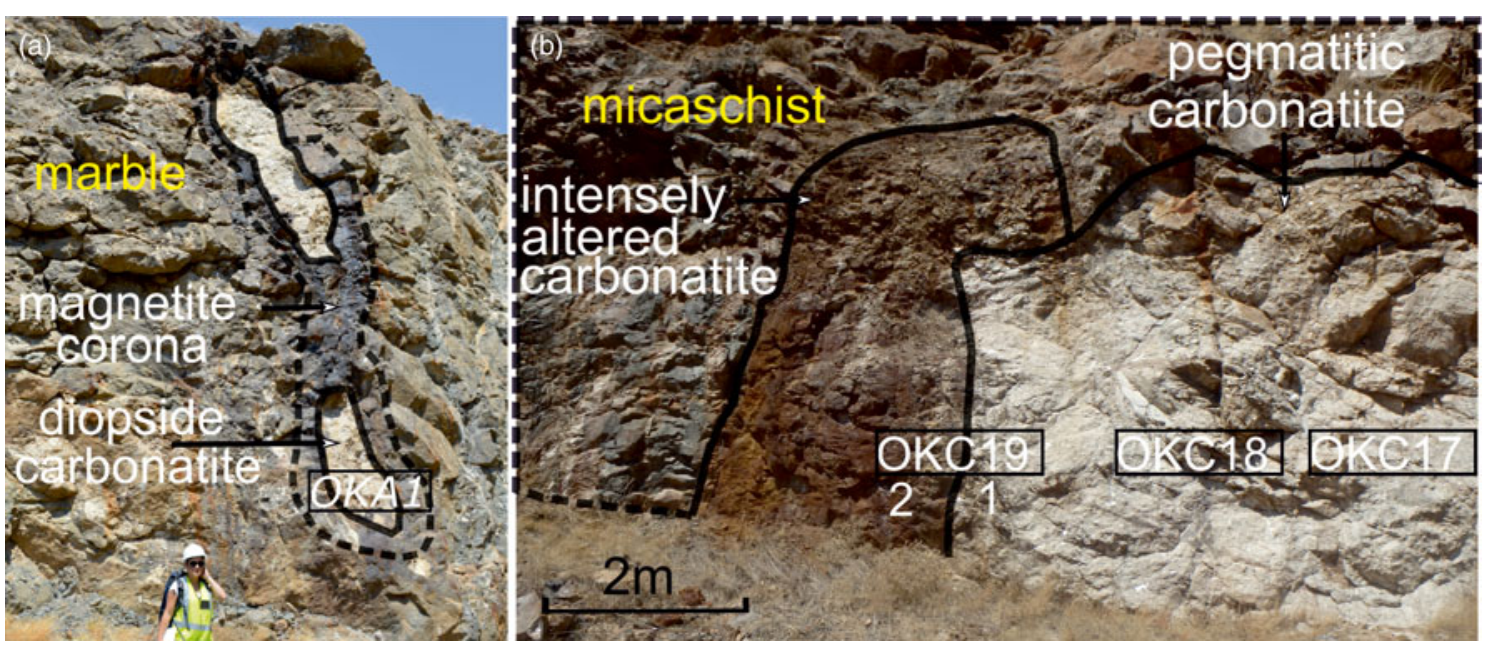

Fig. 3. Field relationships at the sample sites (note 'calcite' from calcite carbonatite is not labelled). (a) OKA1, the altered diopside-bearing calcite carbonatite occurs as two elongated pods with a magnetite aureole. (b) Pegmatitic calcite carbonatite pod with highly altered margin referred to as intensely altered calcite carbonatite (OKC19-2). Samples OKC17 and OKC18 were taken from the middle of the pod, sample OKC19 at the contact with the altered margin.

Table 1. Summary of the mineralogy of the samples investigated (see Figs 2 and 3 for locations) ${ }^{\star}$.

\begin{tabular}{|c|c|c|c|c|}
\hline Sample number & Coordinate & Rock type & Igneous mineralogy (vol.\%) & Hydrothermal mineralogy (vol.\%) \\
\hline OKC4 & $\begin{array}{l}20^{\circ} 2^{\prime} 33^{\prime \prime} \mathrm{S} \\
16^{\circ} 44^{\prime} 22^{\prime \prime} \mathrm{E}\end{array}$ & Mafic dyke with chilled margin & $\begin{array}{l}\text { Ca-Mg bearing aluminium silicate }(5 \%) \text {, } \\
\text { diopside }(5 \%) \text {, magnesiochromite }(<5 \%) \text {, } \\
\text { forsterite }(<5 \%)\end{array}$ & $\begin{array}{l}\text { Actinolite, phlogopite, sodalite, magnetite, pyrite. } \\
\text { Total }=80 \%\end{array}$ \\
\hline OKC4' & $\begin{array}{l}20^{\circ} 2^{\prime} 33^{\prime \prime} \mathrm{S} \\
16^{\circ} 44^{\prime} 22^{\prime \prime} \mathrm{E}\end{array}$ & $\begin{array}{l}\text { Calcite carbonatite replacing } \\
\text { the mafic dyke }\end{array}$ & Calcite $(60 \%)$, apatite $(<5 \%)$ & $\begin{array}{l}\text { Calcite, witherite, strontianite, REE-carbonate. } \\
\text { Total }=35 \%\end{array}$ \\
\hline OKA5 & $\begin{array}{l}20^{\circ} 2^{\prime} 57^{\prime \prime} \mathrm{S} \\
16^{\circ} 44^{\prime} 39^{\prime \prime} \mathrm{E}\end{array}$ & $\begin{array}{l}\text { Diopside-bearing calcite } \\
\text { carbonatite pod }\end{array}$ & $\begin{array}{l}\text { Calcite }(40 \%) \text {, diopside }(30 \%) \text {, apatite } \\
(15 \%) \text {, phlogopite }(5 \%) \text {, pyrite }(5 \%)\end{array}$ & Calcite, iron oxide. Total = 5\% \\
\hline OKA1 & $\begin{array}{l}20^{\circ} 2^{\prime} 57^{\prime \prime} \mathrm{S} \\
16^{\circ} 44^{\prime} 39^{\prime \prime} \mathrm{E}\end{array}$ & $\begin{array}{l}\text { Diopside-bearing calcite } \\
\text { carbonatite pod }\end{array}$ & $\begin{array}{l}\text { Calcite }(25 \%) \text {, diopside }(20 \%) \text {, apatite } \\
(15 \%) \text {, Ti-bearing magnetite }(5 \%)\end{array}$ & $\begin{array}{l}\text { Calcite, dolomite, quartz, iron hydroxide, } \mathrm{K} \text {-feldspar, } \\
\text { strontianite, baryte, parisite, witherite, pyrite, } \\
\text { REE-carbonate, REE-fluorcarbonate. Total }=35 \%\end{array}$ \\
\hline $\begin{array}{l}\text { OKC17, OKC18, } \\
\text { OKC19-1 }\end{array}$ & $\begin{array}{l}20^{\circ} 2^{\prime} 34^{\prime \prime} \mathrm{S} \\
16^{\circ} 44^{\prime} 26^{\prime \prime} \mathrm{E}\end{array}$ & $\begin{array}{l}\text { Pegmatitic calcite carbonatite } \\
\text { pod }\end{array}$ & $\begin{array}{l}\text { Calcite }(45 \%) \text {, apatite }(<10 \%) \text {, Ti-bearing } \\
\text { magnetite }(<5 \%) \text {, Nb-bearing mineral } \\
(<5 \%)\end{array}$ & $\begin{array}{l}\text { Calcite, iron hydroxide, dolomite, pyrite, quartz, } \\
\text { K-feldspar, celestine, baryte, strontianite, parisite, } \\
\text { REE-carbonate, fluorite. Total }=45 \%-65 \%\end{array}$ \\
\hline OKC19-2 & $\begin{array}{l}20^{\circ} 2^{\prime} 34^{\prime \prime} \mathrm{S} \\
16^{\circ} 44^{\prime} 26^{\prime \prime} \mathrm{E}\end{array}$ & $\begin{array}{l}\text { Intensely hydrothermally } \\
\text { altered calcite carbonatite } \\
\text { margin }\end{array}$ & Apatite $(<5 \%)$ & $\begin{array}{l}\text { Calcite }(50 \%) \text {, quartz, dolomite, iron hydroxide, } \\
\text { baryte, strontianite, celestine-baryte, parisite. Total } \\
>95 \%\end{array}$ \\
\hline $\begin{array}{l}\text { OKC3, OKC6, } \\
\text { OKC7, OKC8, } \\
\text { OKC10 }\end{array}$ & $\begin{array}{l}20^{\circ} 2^{\prime} 31^{\prime \prime} \mathrm{S} \\
16^{\circ} 44^{\prime} 24^{\prime \prime} \mathrm{E}\end{array}$ & Fluorite-rich rock & & $\begin{array}{l}\text { Fluorite }(>60 \%) \text {, calcite, quartz, K-feldspar, dolomite, } \\
\text { baryte, parisite. Total }=100 \%\end{array}$ \\
\hline
\end{tabular}

${ }^{*}$ Minerals are listed by order of abundance (only the most abundant hydrothermal minerals are listed here). The estimated percentage (vol.\%) of the igneous minerals refers to the entire calcite carbonatite rock including the hydrothermal minerals.

Silicate domains of intergrown plagioclase (ranging from albite to oligoclase in composition) and phengite with minor phlogopite, dolomite and calcite occur in the least altered diopside-bearing calcite carbonatite (Fig. 4c). At the edges of the silicate domains, coarser-grained diopside and calcite tend to be intergrown with the plagioclase (Fig. 4c). It is possible that these silicate domains are wall-rock xenoliths which have reacted with the carbonatite magma (c.f. Anenburg and Mavrogenes, 2018; Chebotarev et al., 2019).

\section{Stage 3 - Hydrothermal alteration}

All carbonatite samples show some degree of secondary overprinting from hydrothermal fluids. In less-altered examples (e.g. OKA5, Fig. $4 b, c)$, significant magmatic calcite remains, while in the most altered, OKC19-2, the magmatic calcite is completely replaced by coarse hydrothermal calcite with distinctive $\mathrm{Ba}, \mathrm{Sr}$ and REE-bearing mineral inclusions (Fig. $4 d$ ). In detail, hydrothermal calcite is designated as stage $3 \mathrm{a}$, as it is in turn, partially replaced by a spongy matrix of hydrothermal phases assigned to stage $3 \mathrm{~b}$ (Fig. 4h). Apatite is also brecciated in altered areas and stage 3 calcite and quartz have crystallised in the gaps. In the most altered carbonatites, only minor magmatic apatite remains (Fig. $4 l$ ). Parisite is an integral part of stage 3 alteration, occurring in stage $3 \mathrm{~b}$ spongy intergrowths as well as in stage $3 \mathrm{a}$.

Hydrothermal (stage 3) calcite appears dark in BSE images compared to magmatic calcite as a result of low $\mathrm{Sr}$ and $\mathrm{Ba}$ contents (Table 2). In the least altered samples, stage 3 calcite is confined to secondary replacement of magmatic calcite along cleavage planes and grain margins (Fig. $4 b, d$ ). Where alteration is more extensive, stage 3 a calcite pseudomorphs stage 1 calcite (Fig. $4 d$ ). In all cases, stage 3a calcite contains small inclusions (from $<40 \mu \mathrm{m}$ to $<10 \mu \mathrm{m}$ for the least-altered samples) of strontianite, witherite, parisite, baryte, celestine and unidentified 

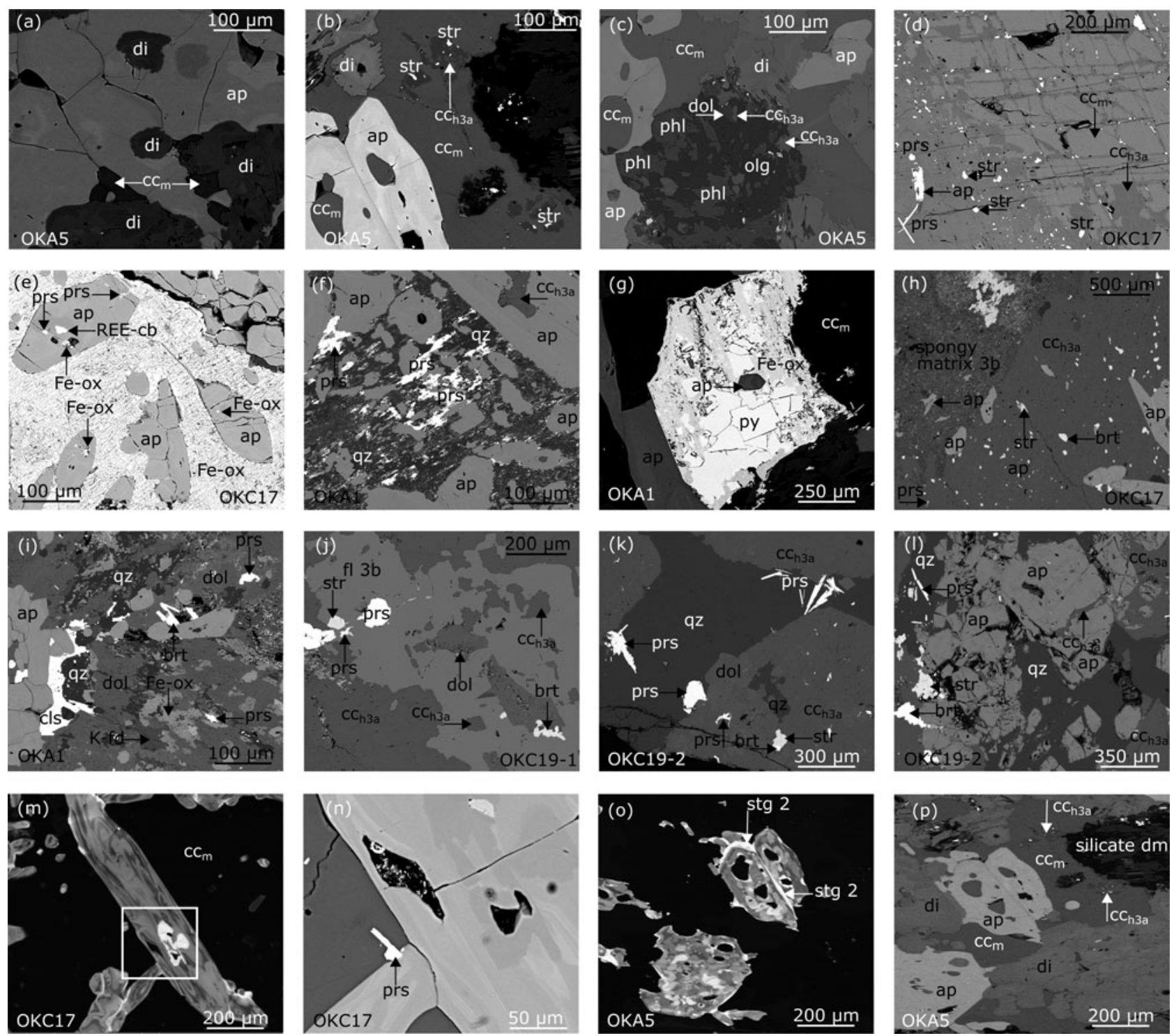

Fig. 4. BSE $(a-l, n, p)$ and $\mathrm{CL}(m, o)$ images of magmatic and hydrothermal alteration textures of the Okorusu calcite carbonatites. (a) Sample OKA5 showing early diopside displaying irregular zoning with a corroded crystal edge enclosed in later magmatic apatite; $(b)$ sample OKA5 with magmatic calcite forming rounded inclusions in apatite, early corroded diopside enclosed in magmatic calcite and hydrothermal calcite (dark grey stage 3a) containing strontianite inclusions; (c) sample OKA5 with a silicate domain of intergrown plagioclase and phlogopite; $(d)$ sample OKC17 showing magmatic calcite replaced along cleavage planes by hydrothermal calcite, strontianite and parisite (stage 3a); (e) sample OKC17 with subhedral to euhedral apatite enclosed in iron hydroxide with parisite and other alteration minerals along the apatite fractures; ( $f$ ) sample OKA1 with variably replaced magmatic apatites in a quartz matrix; parisite occurs as fine grains in the matrix and as replacement of apatite; $(g)$ sample OKA1 with partially oxidised pyrite and a euhedral apatite inclusion; $(h)$ sample OKC17 showing recrystallised calcite (stage 3a), strontianite and baryte inclusions, corroded by a spongy assemblage (stage 3b), magmatic apatite occurs in both hydrothermal assemblages; (i) sample OKA1 with magmatic apatite in extensively recrystallised matrix (stage 3a) consisting of dolomite, iron hydroxide, K-feldspar, quartz, celestine, baryte and parisite; $(j)$ sample OKC19-1 with stage 3 b fluorite partially replacing stage 3a calcite; $(k)$ sample OKC19-2 with coarse euhedral parisite intergrown with stage 3a quartz and calcite; $(l)$ sample OKC19-2 with relict of igneous apatite fractured by stage 3a calcite associated with quartz, strontianite, baryte and parisite mineralisation; $(m)$ SEM-CL image of apatite in sample OKC17; Stage 1 apatite exhibits complex zoning in lower intensity greys while stage 2 apatite is the distinctive bright material on rims, in late cracks and in an irregular central pore-filling; $(n)$ BSE image of the inset shown in $(m)$, with a euhedral parisite embedded at the edge of the apatite, note that the stage 2 apatite corresponds here to the darkest zone; (o) SEM-CL image of apatite in sample OKA5 showing stage 2 apatite; ( $p$ ) BSE

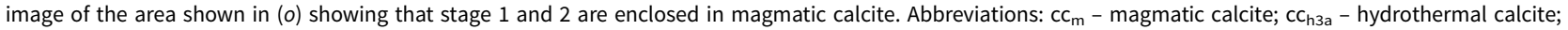
di - diopside; ap - apatite; str - strontianite; phl - phlogopite; olg - oligoclase; dol - dolomite; prs - parisite; $R E E$-cb - REE-carbonate; Fe-ox - unidentified Fe hydroxide; qz - quartz; py - pyrite; brt - baryte; K-fd - K-feldspar; cls - celestine; fl - fluorite, stg 2 - stage 2 apatite; silicate dm - silicate domain.

$R E E$-fluorcarbonate and REE-carbonate (Figs $4 b, d, 6$ ). In the pegmatitic calcite carbonatite, stage 3 a calcite is more abundant and the inclusions are coarser $(50 \mu \mathrm{m}$ to $300 \mu \mathrm{m})$ towards the contact with the intensely altered calcite carbonatite (OKC19-2) where the magmatic calcite was completely replaced by stage 3 a calcite.

The stage $3 a$ inclusion phases, such as celestine, baryte and parisite (Fig. 6), can also occur with iron hydroxides (Fig. 4e) and quartz in the rock matrix. The hydrothermal iron hydroxide may be goethite or limonite. Iron hydroxides occur infilling fractures and replacing magmatic apatite (Fig. 4e). In the altered diopside-bearing calcite carbonatite, medium-grained apatite is locally brecciated and infilled with stage 3 quartz and parisite (Figs $4 f, 6$ ). Apatite is the only magmatic mineral remaining in the intensely altered calcite carbonatite (OKC19-2; Fig. 3b); it is 


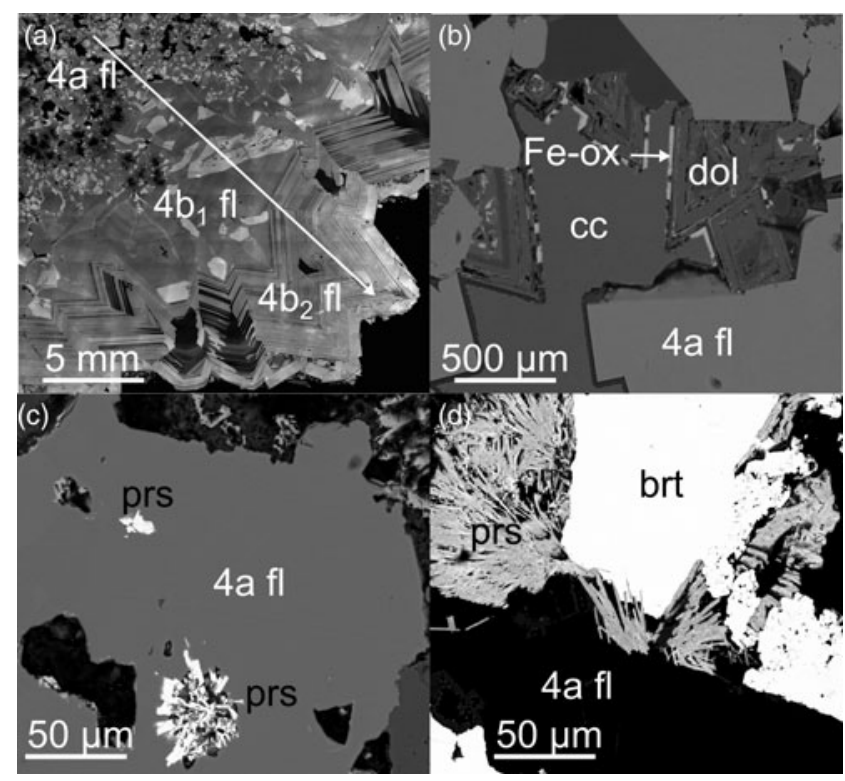

Fig. 5. $\mathrm{CL}$ and BSE images illustrating stage 4 textures. (a) SEM-CL image showing the sequential crystallisation represented by the arrow of type $4 a$ and type $4 b$ fluorite (sample OKC6); (b) BSE image demonstrating the sequential crystallisation of type 4a fluorite, quartz, dolomite, iron hydroxide and stage 4 calcite, note that the Fe and $\mathrm{Mg}$ content of dolomite varies (OKC3); (c) BSE image of parisite mineralisation embedded in a cavity lining in type 4 a fluorite (OKC8); (d) BSE image of radiating parisite crystals growing into baryte in type 4a fluorite (OKC8). brecciated and in-filled by stage 3a calcite with minor baryte, strontianite, celestine and iron hydroxide (Fig. 4l). Apatites are dissolved locally where stage 3a parisite has crystallised (Fig. $4 f$ ). Regardless of stage 3 alteration, some apatite crystals which were altered extensively have unaltered regions which retain the CL pattern of stage 1 (oscillatory grey SEM-CL) and stage 2 apatite (bright SEM-CL) seen in less altered samples.

Stage 1 pyrite and Ti-bearing magnetite are replaced partially by stage 3 iron hydroxide minerals (Fig. $4 e, g$ ) while the $\mathrm{Nb}$-bearing phases in the pegmatitic calcite carbonatites are extensively overprinted by stage 3 alteration, including growth of celestine in the rims. Minor fluorite occurs in stage 3, where it appears to be cogenetic with iron hydroxide, replacing stage 1 pyrite and partially replacing stage $3 \mathrm{a}$ calcite in both calcite carbonatite types (Fig. $4 j$ ).

Stage $3 \mathrm{~b}$ overprints stage $3 \mathrm{a}$ (Fig. $4 h$ ), and is characterised by the development of a spongy assemblage of porous dolomite and K-feldspar, with quartz, iron hydroxide, celestine, baryte, and accessory parisite, pyrite, Ti oxide and sphalerite. The texture of the porous dolomite and $\mathrm{K}$-feldspar contrasts with stage $3 \mathrm{a}$ calcite which is well crystallised, but it is probable that stage 3 dolomite coexisted with calcite (Fig. 4i). Stage 3 REE minerals, mainly parisite and other REE carbonates, occur as inclusions in stage 3 a calcite, in cracks cutting and replacing both stage 1 and 2 apatite (Fig $4 e, f)$, and in altered diopside.

Stage 3 alteration products are coarser grained in the more intensely altered rocks, with parisite forming euhedral crystals

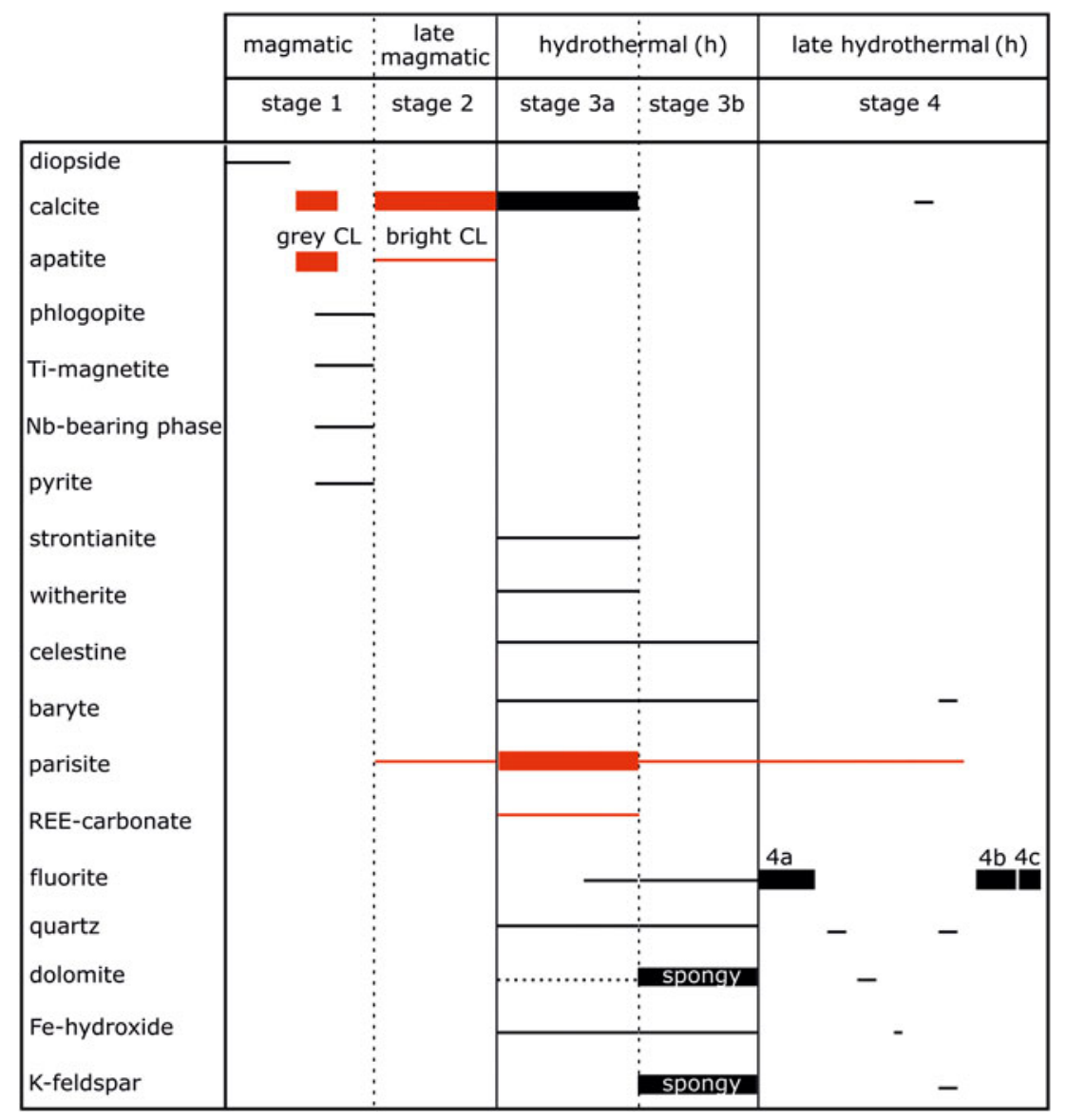

Fig. 6. Simplified paragenetic diagram of the Okorusu carbonatite deposit illustrating the REE reworking from magmatic (associated to gangue minerals) to hydrothermal as REE minerals. Bar thickness represents mineral abundance. Red bars represent the main $R E E$-bearing minerals in each stage. 
up to $400 \mu \mathrm{m}$ long in OKC19-2 (Fig. $4 k$ ). Intensely altered calcite carbonatite has the highest content of secondary sulfate minerals, with stage 3 anhedral strontianite commonly hosting baryte inclusions.

\section{Stage 4 - Fluorite mineralisation}

Massive fluorite replaces country rock marble as well as carbonatite bodies at Okorusu (Hagni and Shivdasan, 2000) and is described here as stage 4 alteration, although the scale of change in rock composition is much greater than for stage 3 alteration. Optical and SEM-CL imaging indicate three main fluorite generations formed during stage 4 . The earliest fluorite, type $4 \mathrm{a}$, occurs as small cubes (average $0.5 \mathrm{~mm}$ ), typically exhibiting oscillatory growth zoning. Type $4 \mathrm{~b}$ fluorite comprises coarse euhedral crystals $(\geq 1 \mathrm{~cm})$ in voids; which can be divided into an earlier, unzoned stage (type $4 \mathrm{~b}-1$ ) and later (type 4b-2) material with oscillatory euhedral growth zoning (Fig. 5a). Type $4 \mathrm{a}$ and $4 \mathrm{~b}$ fluorite often developed sequentially (Fig. 5a). Finally, type $4 \mathrm{c}$ fluorite seals healed cracks which crosscut the earlier fluorite generations.

Minor amounts of other minerals may accompany stage 4 fluorite, mainly growing between type $4 \mathrm{a}$ and type $4 \mathrm{~b}$ fluorite, although these are not always present (Fig. 5). Type 4a fluorite is overgrown by a veneer of quartz, itself overgrown by dolomite, minor iron hydroxide and stage 4 calcite. The coexistence of quartz and dolomite requires a low temperature for this stage. This sequence of minerals was subsequently corroded and partially replaced by quartz, K-feldspar and minor baryte (Figs $5 b, 6$ ) prior to the growth of Type $4 \mathrm{~b}$ fluorite. Bühn et al. (2003) divided the fluorite into types based on hand specimens and fluorite textures, whereas we have categorised them based on SEM-CL images. Type 4a fluorite from this study matches fluorite they observed in the metasomatised wallrock, while type $4 \mathrm{~b}$ fluorite corresponds to their fluorite II. They also described feldspar and quartz with resorbed grains boundaries, but interpreted these textures as possible relicts of feldspar-bearing protoliths or as fluorite cogenetic phases observed in the metasomatised wall rock. Early fluid-inclusion studies of the fluorite ore at Okorusu (Roedder, 1973), and subsequent work (Bühn et al., 2002), yielded fluid salinities up to $5 \mathrm{wt} . \% \mathrm{NaCl}$ equivalent and homogenisation temperatures between $120^{\circ} \mathrm{C}$ and $150^{\circ} \mathrm{C}$.

While the stage 4 mineral assemblage is dominated by fluorite (Table 1 ) it contains a similar mineral suite to stage $3 \mathrm{~b}$, with coexisting calcite and dolomite, parisite, fluorite, baryte, quartz, iron hydroxide and K-feldspar in both stages. Stage 4 may fully replace the partially altered stage 3 calcite carbonatites (Hagni and Shivdasan, 2000). Overall, the fluorite orebody replaces calcite. If this process occurred without addition or removal of $\mathrm{Ca}$, it implies a solid volume decrease of $33.5 \%$ (Glover and Sippel, 1962), which would probably result in an increase in porosity and so enhance fluid flow via a positive feedback. Some such feedback may explain the formation of the coarse euhedral stage $4 \mathrm{~b}$ fluorite which crystallised in the voids created by the replacement process.

Rare-earth mineralisation during stage 4 alteration occurs solely in association with type 4 a fluorite. This contains discrete inclusions and elongate crystals of parisite embedded in cavity linings (Fig. 5c), crosscutting quartz and K-feldspar or associated with baryte as radiating crystals locally growing into the baryte (Fig. $5 d$ ).

\section{Mineral compositions and trace-element abundancies}

\section{Stage 1 magmatic phases}

Calcite

Calcite is the most abundant magmatic phase in the Okorusu carbonatite. In both the diopside-bearing and pegmatitic calcite carbonatites the $\mathrm{CaCO}_{3}$ component $>95$ mol.\%. In detail, magmatic calcite in the least altered diopside-bearing calcite carbonatite has slightly lower $\mathrm{Mg}$ and $\mathrm{Fe}$ contents than magmatic calcite in other samples (Table 2). As with calcite carbonatites elsewhere (Chakhmouradian et al., 2016; Chakhmouradian et al., 2017), magmatic calcite has a high Sr content (usually >2 wt.\% SrO; Table 2) with $\mathrm{Ba}$ as the next most abundant cation. The $\Sigma L R E E$ content tends to be higher in pegmatitic calcite carbonatite than diopside-bearing calcite carbonatites (averaging $\Sigma L R E E=$ $1350 \mathrm{ppm}$ and $\Sigma L R E E=910 \mathrm{ppm}$, respectively. $\mathrm{La}$ and $\mathrm{Ce}$ are the most abundant lanthanides). Overall, $\Sigma H R E E$ ( $\Sigma H R E E=$ $\mathrm{Eu}-\mathrm{Lu})$ contents are low in magmatic calcite averaging $<20 \mathrm{ppm}$ (Table 2), comparable to magmatic calcite from calcite carbonatites elsewhere (Chakhmouradian et al., 2016) (Table 2). The calcite analyses are presented in Appendix 3.

\section{Diopside}

Diopsides are formally part of the diopside group and range into ferrian and ferro sodian diopside (Sturm, 2002). Most of the diopsides have $\mathrm{Na}_{2} \mathrm{O}$ ranging from $0.75 \mathrm{wt} . \%$ to $1 \mathrm{wt} . \%$, although some grain cores of ferro-sodian diopside have $\mathrm{Na}_{2} \mathrm{O}$ up to 2.25 wt.\%. Diopside in the carbonatites is clearly distinct from aegirine, which is typical of fenite (Zharikov et al., 2007); this implies that the diopside is magmatic, as indicated by the textures. Diopside EMPA and LA-ICP-MS analyses are presented in Appendix 3. The diopside has low concentrations of REE ( $\Sigma R E E$ ranging from 11-135 ppm) with the heaviest $R E E$ lower than the limit of detection. Compared to the other minerals it shows a $L R E E$ enriched profile but the $L R E E$ pattern is flattened with $\mathrm{Ce}(\mathrm{cn})>\mathrm{La}(\mathrm{cn})$, this curvature is characteristic of clinopyroxene from carbonatites (Reguir et al., 2012) (Fig. 7, cn = chondrite normalised).

\section{Apatite}

Semi-quantitative analyses confirm that 'apatites' are fluorapatites which are the main magmatic host for the REE at Okorusu (Fig. 7). Apatites from the diopside-bearing and pegmatitic calcite carbonatites are similar in composition and comparable to apatites from other carbonatites (Chakhmouradian et al., 2017; Belousova et al., 2002), although Sr is relatively high (1.5 to $2 \mathrm{wt. \%}$ SrO; Table 3). In contrast, apatite inclusions hosted in magmatic calcite from the calcite carbonatite replacing the mafic dyke core (OKC4, Table 1), are distinctly enriched in $\mathrm{Na}$ and the REE but are depleted in Th (Table 3 ).

The narrow textural zonations made it difficult to analyse individual apatite growth stages (Fig. $4 m, o$ ), especially by LA-ICP-MS, but some individual analyses of stage 1 and 2 apatite are provided in Appendix 3. Stage 2 apatite has lower concentrations of the $R E E$ relative to stage 1 , especially for the LREE (Fig. 8), and this may reflect the crystallisation of cogenetic parisite. As both stages of apatite have very similar normalised REE trends (Fig. 7) despite the differences in concentrations, exchange of $R E E$ with an external reservoir can probably be ruled out. 


\section{Stage 3: chemical changes accompanying hydrothermal alteration of calcite}

\section{Calcite}

Stage 3a calcite is chemically distinct from magmatic calcite (Table 2). Being very pure $\left(\mathrm{CaCO}_{3}\right.$ component $\left.>98 \mathrm{~mol} . \%\right)$ the hydrothermal calcite is depleted in the major additional cations, $\mathrm{Sr}, \mathrm{Ba}$ and in REE (Fig. 9; Table 2). Overall, $\mathrm{Mg}, \mathrm{Mn}$ and $\mathrm{Fe}$, while still very low, are slightly enriched compared to the magmatic calcite (Fig. 9a; Table 2) and stage 3a calcite exhibits $\mathrm{Mn}-\mathrm{Fe}$ zonation observed in SEM imaging in the intensely altered calcite carbonatite. Only yttrium does not show the intense depletion of the other REE (Fig. 9b), and is within error of the concentrations in magmatic calcite.

Stage 3 alteration involved the growth of a suite of hydrothermal minerals, including strontianite, witherite, baryte and parisite (Fig. $4 b, d$ ), and these are likely to be repositories for the elements released during hydrothermal alteration of magmatic minerals.

\section{Parisite}

Parisite is the principal $R E E$ mineral in the calcite carbonatite sample suite (average $\Sigma R E E_{2} \mathrm{O}_{3 \text { tot }}$ in stage 3 parisite from the calcite carbonatite 47 wt.\%) (Fig. 7; Appendix 3). The parisite REE pattern is broadly similar to those of the magmatic phases (Fig. 7) but shows even stronger LREE enrichment than apatite.

\section{Stage 4 alteration: REE behaviour in fluorite mineralisation}

LA-ICP-MS analyses of stage $3 \mathrm{~b}$ and stage 4 fluorite are given in Appendix 3. All fluorite generations have low concentrations of $R E E$, with the HREE below detection except for $\mathrm{Y}$, and a positive $\mathrm{Y}$ anomaly of a few ppm to a few hundred ppm, as is common for fluorite (Williams-Jones and Palmer, 2002; Nadoll et al., 2018). Stage 4a fluorite coexists with parisite (Fig. $5 c-d$ ) and has the highest LREE contents, averaging $\Sigma L R E E \sim 145 \mathrm{ppm}$; type $4 \mathrm{c}$ fluorite has an average $\Sigma L R E E$ slightly higher than type $4 \mathrm{~b}$ fluorite ( $\Sigma L R E E \sim 60$ ppm).

The composition of stage 4 parisite was difficult to quantify because of fine scale intergrowth with Fe hydroxides and other phases. It apparently has a somewhat higher REE content than stage 3 parisite (average $\Sigma R E E_{2} \mathrm{O}_{3 \text { tot }}=58$ wt.\%), although this could be an artefact of the associated Fe hydroxides. Associated stage 4 calcite has a very low $L R E E$ content (average $\Sigma R E E_{\text {tot }(\mathrm{La}-\mathrm{Nd})}$ $<40 \mathrm{ppm}$ ) with no detectable HREE, even though both stage $3 \mathrm{a}$ and stage 4 calcite coexist with parisite (Appendix 3 ).

\section{Minor and trace element redistribution during hydrothermal alteration of calcite carbonatite}

\section{Primary magmatic variation:}

The suite of rocks studied shows a broad increase in REE contents from mafic rocks to carbonatites. Most of the major element

Table 2. Average LA-ICP-MS compositions of magmatic and stage 3a hydrothermal calcite from the Okorusu calcite carbonatites*.

\begin{tabular}{|c|c|c|c|c|c|c|c|c|}
\hline & \multirow{2}{*}{$\begin{array}{l}\text { OKC4 } \\
m=15\end{array}$} & \multirow{2}{*}{$\begin{array}{l}\text { OKA5 } \\
\qquad \begin{array}{c}\mathrm{m} \\
n=19\end{array}\end{array}$} & \multicolumn{2}{|c|}{ OKA1 } & \multicolumn{2}{|c|}{ OKC17 } & \multirow{2}{*}{$\begin{array}{l}\text { OKC19-1 } \\
\qquad \begin{array}{c}\mathrm{m} \\
n=5\end{array}\end{array}$} & \multirow{2}{*}{$\begin{array}{c}\text { OKC19-2 } \\
\begin{array}{l}\text { stg } 3 a \\
n=27\end{array}\end{array}$} \\
\hline & & & $\underset{n=20}{m}$ & $\begin{array}{c}\operatorname{stg} 3 a \\
n=7\end{array}$ & $\underset{n=18}{m}$ & $\begin{array}{c}\operatorname{stg} 3 a \\
n=10\end{array}$ & & \\
\hline \multicolumn{9}{|l|}{ wt.\% } \\
\hline $\mathrm{CaO}$ & 52.98 & 52.32 & 52.34 & 54.45 & 53.97 & 55.77 & 53.44 & 54.15 \\
\hline SrO & 1.36 & 2.05 & 2.55 & 0.89 & 2.49 & 0.55 & 2.39 & 0.29 \\
\hline $\mathrm{BaO}$ & 0.43 & 0.34 & 0.23 & n.d. & 0.27 & 0.01 & 0.23 & n.d. \\
\hline $\mathrm{MnO}$ & 0.19 & 0.05 & 0.07 & 0.16 & 0.09 & 0.16 & 0.05 & 0.59 \\
\hline $\mathrm{FeO}$ & 0.24 & 0.01 & 0.07 & 0.31 & 0.11 & 0.32 & 0.06 & 0.53 \\
\hline $\mathrm{MgO}$ & 0.22 & 0.01 & 0.04 & 0.10 & 0.05 & 0.05 & 0.05 & 0.15 \\
\hline \multicolumn{9}{|c|}{ Atoms per formula unit } \\
\hline $\mathrm{Ca}$ & 0.97 & 0.98 & 0.97 & 0.98 & 0.97 & 0.99 & 0.97 & 0.98 \\
\hline $\mathrm{Sr}$ & 0.01 & 0.02 & 0.02 & 0.01 & 0.02 & 0.005 & 0.02 & 0.003 \\
\hline $\mathrm{Ba}$ & 0.003 & 0.002 & 0.002 & n.d. & 0.002 & $<0.001$ & 0.002 & n.d. \\
\hline $\mathrm{Mn}$ & 0.003 & $<0.001$ & 0.001 & 0.00 & 0.001 & 0.002 & 0.001 & 0.01 \\
\hline $\mathrm{Fe}$ & 0.003 & $<0.001$ & 0.001 & 0.00 & 0.001 & 0.004 & 0.001 & 0.01 \\
\hline $\mathrm{Mg}$ & 0.01 & $<0.001$ & 0.001 & 0.00 & 0.001 & 0.001 & 0.001 & 0.004 \\
\hline \multicolumn{9}{|c|}{ Average $\mathrm{ppm}^{\star \star}$} \\
\hline $\mathrm{Na}$ & $152(122)$ & n.d. & n.d. & $123(86)$ & $146(60)$ & n.d. & $146(16)$ & n.d. \\
\hline La & $482(372)$ & $314(55)$ & $344(138)$ & $117(27)$ & $508(121)$ & $19(12)$ & $482(32)$ & $4(3)$ \\
\hline $\mathrm{Ce}$ & $570(450)$ & $414(86)$ & 468 (175) & $175(44)$ & $679(143)$ & $32(20)$ & $630(37)$ & $7(6)$ \\
\hline $\operatorname{Pr}$ & $41(33)$ & $32(9)$ & $34(13)$ & $13(3)$ & $53(12)$ & $3(2)$ & $46(3)$ & $1(2)$ \\
\hline $\mathrm{Nd}$ & $111(89)$ & $95(30)$ & $103(38)$ & $37(7)$ & $151(31)$ & $9(6)$ & $126(8)$ & $3(6)$ \\
\hline Sm & $13(11)$ & $9(5)$ & $10(3)$ & n.d. & $12(3)$ & n.d. & $11(2)$ & $<1(<1)$ \\
\hline $\mathrm{Eu}$ & $4(3)$ & $2(1)$ & $3(1)$ & n.d. & $3(1)$ & n.d. & $3(<1)$ & $<1(<1)$ \\
\hline $\mathrm{Gd}$ & $10(8)$ & $5(5)$ & $9(4)$ & $3(<1)$ & $8(2)$ & n.d. & $8(1)$ & $1(1)$ \\
\hline $\mathrm{Tb}$ & $1(1)$ & n.d. & $1(<1)$ & n.d. & $1(<1)$ & n.d. & $1(<1)$ & $<1(<1)$ \\
\hline Dy & $7(5)$ & n.d. & $5(1)$ & $2(<1)$ & $3(1)$ & $1(1)$ & $2(<1)$ & $4(1)$ \\
\hline Ho & $1(1)$ & n.d. & $1(<1)$ & n.d. & $<1(<1)$ & $<1(<1)$ & $1(<1)$ & $1(<1)$ \\
\hline $\mathrm{Er}$ & $5(3)$ & n.d. & $2(1)$ & n.d. & $1(1)$ & $1(1)$ & $1(1)$ & $7(3)$ \\
\hline $\mathrm{Tm}$ & $1(1)$ & n.d. & n.d. & n.d. & n.d. & n.d. & n.d. & $6(5)$ \\
\hline $\mathrm{Yb}$ & $6(4)$ & n.d. & n.d. & n.d. & n.d. & $2(1)$ & $1(<1)$ & $19(11)$ \\
\hline Lu & n.d. & n.d. & n.d. & n.d. & n.d. & n.d. & n.d. & $3(2)$ \\
\hline$Y$ & $57(18)$ & $15(7)$ & $27(5)$ & $14(7)$ & $19(2)$ & $14(12)$ & $17(1)$ & $51(26)$ \\
\hline Th & n.d. & n.d. & n.d. & n.d. & n.d. & n.d. & n.d. & n.d. \\
\hline
\end{tabular}

*LA-ICP-MS data were calculated using the calcium content determined by EMPA. n.d. = not detected as below LA-ICP-MS detection limit. U is below the detection limit for all analyses. Abbreviations: $\mathrm{m}$ - magmatic; stg $3 \mathrm{a}$ - stage $3 \mathrm{a}$.

${ }^{\star \star} \mathrm{ppm}$ values are the average with one standard deviation in brackets. 


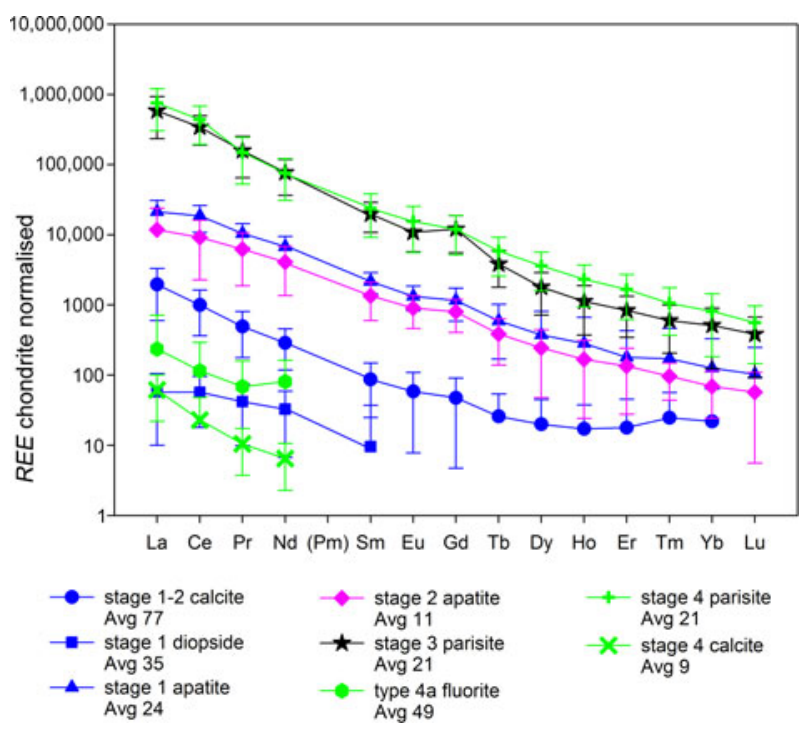

Fig. 7. REE distribution of the REE-bearing minerals observed in magmatic stages 1 and 2 (blue, pink) and hydrothermal stages 3 and 4 (black and green). Type $3 b$ and $4 \mathrm{c}$ fluorite are omitted due to their low REE content (Appendix 3). Data are chondrite normalised (McDonough and Sun, 1995). Data from EMPA and LA-ICP-MS analyses, error bars represent two standard deviations of the average value, some of the error bars are not visible due to the $y$-axis log scale. variations reflect the different proportion of calcite and silicate minerals (Table 4) in the different rock types. The margin of the mafic dyke (OKC4) has the lowest REE content, but all REE patterns are similar (Fig. 10). The mafic dyke core, which was subsequently intruded by calcite carbonatite, shows $L R E E$ depletion compared to the magmatic calcite carbonatites because apatite and calcite are less abundant. The mafic dyke core is also depleted in HREE, but to a lesser extent than the LREE, compared to the other calcite carbonatites. This reflects the higher total HREE content of apatite and calcite from the mafic dyke (Tables 2, 3). In contrast, the least altered diopside-bearing calcite carbonatite (OKA5) has a distinctly higher HREE content compared to other magmatic calcite carbonatites (Fig. 10; OKA1, OKC17, 18, 19-1), although no specific mineralogical host for the HREE has been identified.

\section{Variation with hydrothermal alteration:}

In order to evaluate the scale of element redistribution during hydrothermal alteration, we carried out bulk analyses on a range of relatively altered to relatively unaltered calcite carbonatites (Table 4). A simplified mass balance illustrates that for the less altered, pegmatitic calcite carbonatite (sample OKC17) there is no significant change in total REE content due to hydrothermal alteration. Calcite and apatite are respectively $95 \%$ and

Table 3. Average apatite compositions for the Okorusu igneous rocks. *

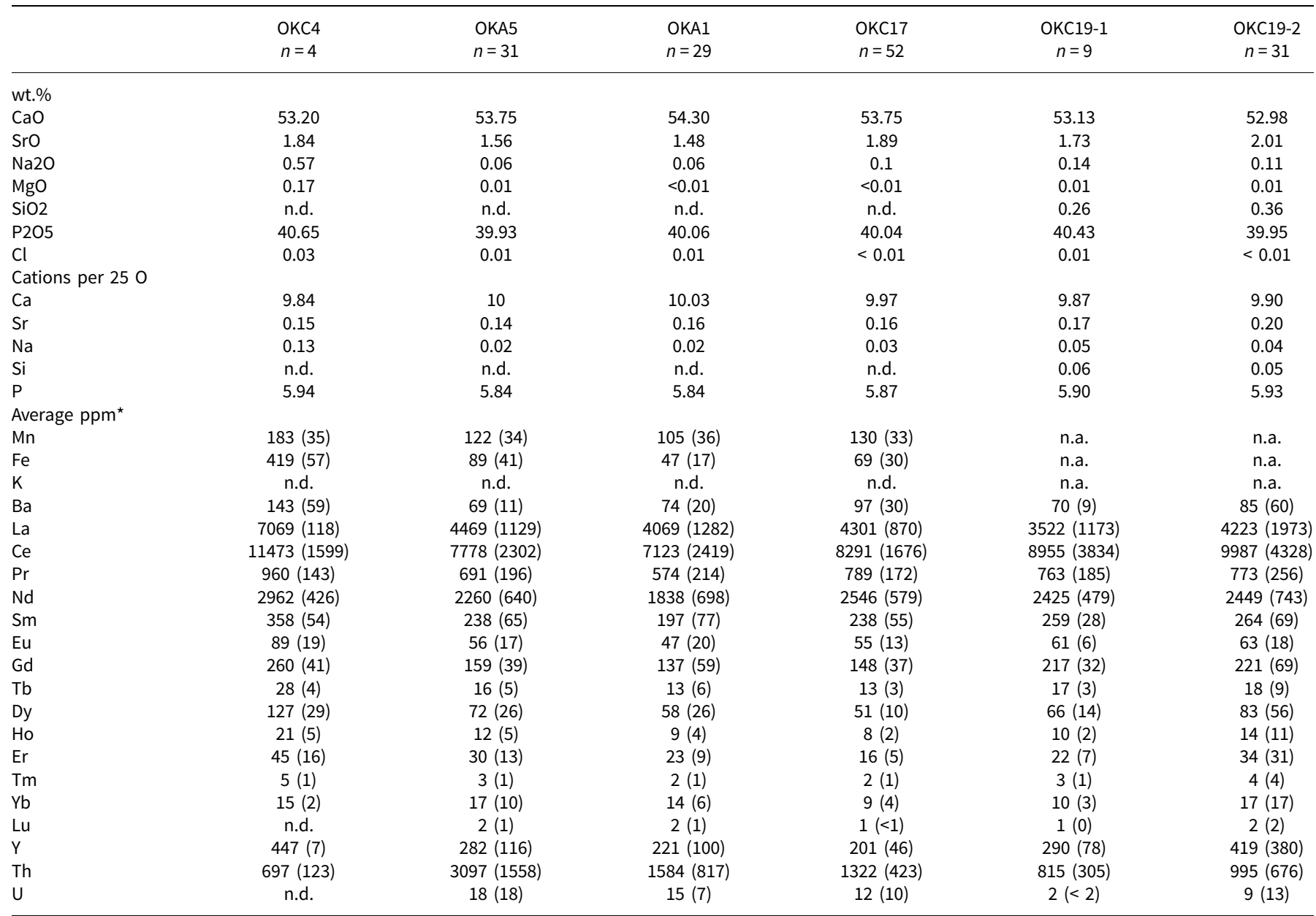

${ }^{*} \mathrm{CaO}$, and $\mathrm{P}_{2} \mathrm{O}_{5}$ and $\mathrm{Cl}$ were determined by EMPA and $\mathrm{Ca}$ was used to calculate the LA-ICP-MS analyses. $n . d .=$ not detected as below LA-ICP-MS detection limit

${ }^{\star \star}$ Average ppm values with one standard deviation in brackets 


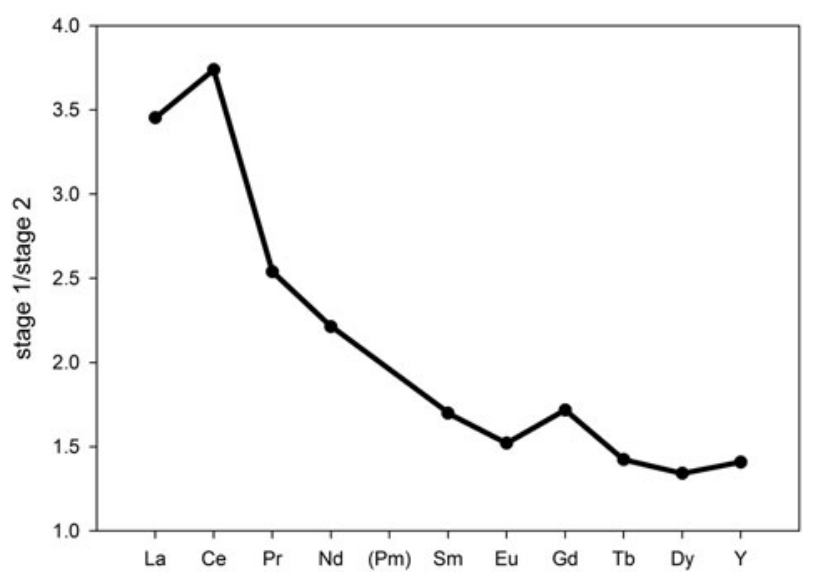

Fig. 8. Ratio of REE concentration in stage 1 vs. stage 2 apatite of sample OKC19-2, stage 1 apatite $n=12$ and stage 2 apatite $n=6$. Ho-Lu were omitted due to the low concentration $(<30 \mathrm{ppm})$ of these elements in both apatite types.

$5 \%$ of the original REE-bearing minerals in sample OKC17 (Table 4) and together made up $\sim 95 \%$ of the sample initially. On the basis of their $\Sigma R E E$ concentrations prior to hydrothermal alteration (Tables 2, 3) we can calculate the original $\Sigma R E E$ concentration of the rock prior to alteration as $2090 \mathrm{ppm}$. The analysed bulk $\Sigma R E E$ content of the sample after alteration is $2190 \mathrm{ppm}$ (Table 4). These values are effectively identical within uncertainty and we conclude that, during alteration, the $R E E$ released from magmatic minerals were retained in the rock but no additional $R E E$ were added.

In contrast, a similar calculation for the more altered pegmatitic calcite carbonatite sample OKC19-1 and the intensely altered pegmatitic carbonatite sample OKC19-2, shows addition of REE. In sample OKC19-1, calcite and apatite represent 95\% and 5\%, respectively, of the original $R E E$-bearing minerals, and together they made up $\sim 95 \%$ of the rock (Table 4 ). Based on the magmatic mineral compositions (Tables 2, 3), the $\Sigma R E E$ content of the original rock was $1989 \mathrm{ppm}$ whereas the $\Sigma R E E$ of the present, altered sample is 2943 ppm (Table 4), suggesting that REE may have been added during alteration. In the intensely altered calcite carbonatite (OKC19-2), calcite and apatite represent respectively $99 \%$ and $1 \%$ of the original REE-bearing minerals and the sample now has $\sim 18 \%$ of added secondary silicates. No magmatic calcite remains in this sample, so we have assumed that it had the same composition as the magmatic calcite in sample OKC19-1, which was adjacent. Assuming there were no other minerals in the original rock, the magmatic calcite and apatite compositions (Tables 2,3) allow us to estimate an original $\Sigma R E E$ content of $1501 \mathrm{ppm}$ for the rock prior to alteration. This is markedly lower than the $\Sigma R E E$ content of the present rock, which is at least $6758 \mathrm{ppm}$ (Table 4, note that $\mathrm{Ce}$ and La values are minima). Allowing for dilution by added hydrothermal silicates, the $\Sigma R E E$ content of the altered carbonatite is now at least $8241 \mathrm{ppm}$, i.e. very much higher than that of the original rock. The present $R E E$ concentrations in OKC19-2 reflect the abundant parisite in this intensely altered carbonatite (Figs $4 k, 10$ ). We conclude that, although the mineralogical changes characteristic of hydrothermal alteration did not always lead to increased REE levels, the more intensely altered samples are rich in parisite and have enhanced levels of REE compared to their magmatic precursors.

Barium and strontium exhibit similar behaviour to the REE. Magmatic calcite is the main repository of $\mathrm{Ba}$ and $\mathrm{Sr}$ in the
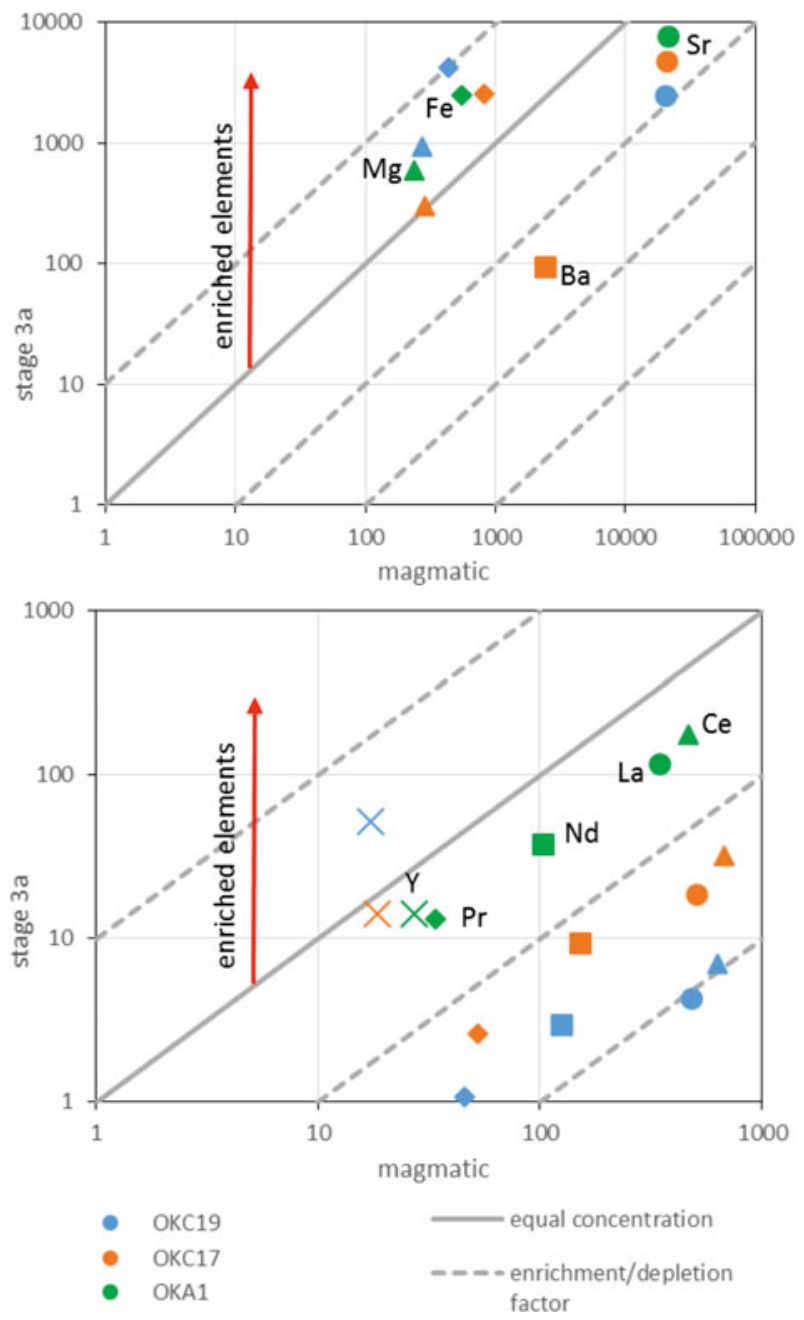

Fig. 9. Comparisons of the composition of magmatic and hydrothermal (stage 3a) calcite to illustrate the changes accompanying recrystallisation. Compositions plotted are element ppm. The calcite carbonatite samples are described in Table 1. (a) Major elements including Sr and Ba (Table 2); (b) binary plot of the average trace element of the magmatic and stage $3 a$ calcite of the diopside-bearing and pegmatitic calcite carbonatites. Data are in ppm from EMPA and LA-ICP-MS analyses. The different samples are colour coded, and each shape represents one element.

least altered rocks (Table 2), and stage 3 hydrothermal recrystallisation to a low-Ba, low-Sr calcite was accompanied by growth of $\mathrm{Ba}$ and $\mathrm{Sr}$ hydrothermal phases including baryte, witherite, strontianite and celestine. Table 4 shows that the $\mathrm{Ba} / \mathrm{Ca}$ ratio of the calcite carbonatites increases with increasing degree of stage 3 alteration, with the markedly higher values for sample OKC19-2. Regarding the REE, the least altered samples show little evidence for enrichment in $\mathrm{Ba}$, despite the appearance of baryte, however there was significant enrichment in $\mathrm{Ba}$ in the most altered sample, OKC19-2. The true Sr concentrations of the pegmatitic calcite carbonatites are above the calibrated range of the whole rock analyses (>10,000 ppm) (Table 4), but based on the modal abundance of Sr-bearing minerals in these samples it is likely that $\mathrm{Sr}$, such as $\mathrm{Ba}$, was also enriched during stage 3 alteration.

The enrichment in REE and Ba suggests that stage 3 alteration involves not just redistribution of minor and trace elements from magmatic minerals to hydrothermal phases on the hand specimen scale, but also some movement on a larger scale. The diopside- 
Table 4. Bulk-rock compositions of the Okorusu igneous rocks described in Table $1 .^{\star}$

\begin{tabular}{|c|c|c|c|c|c|c|c|c|}
\hline & $\mathrm{OKC} 4 \mathrm{~m}$ & $\mathrm{OKC} 4 \mathrm{C}$ & OKA5 & OKA1 & OKC18 & OKC17 & OKC19-1 & OKC19-2 \\
\hline \multicolumn{9}{|c|}{ Major elements (wt.\%) } \\
\hline $\mathrm{F}$ & 0.11 & 0.58 & 0.49 & 0.46 & 0.42 & 0.37 & 0.31 & 0.13 \\
\hline $\mathrm{SiO}_{2}$ & 41.38 & 27.49 & 35.94 & 24.07 & 3.62 & 0.79 & 1.00 & 19.03 \\
\hline $\mathrm{Al}_{2} \mathrm{O}_{3}$ & 10.44 & 6.91 & 4.14 & 0.49 & 0.18 & 0.03 & 0.07 & 0.06 \\
\hline $\mathrm{Fe}_{2} \mathrm{O}_{3}$ tot & 8.72 & 7.29 & 9.10 & 19.65 & 2.28 & 1.75 & 1.41 & 1.42 \\
\hline $\mathrm{MnO}$ & 0.16 & 0.22 & 0.47 & 0.67 & 0.13 & 0.11 & 0.15 & 0.51 \\
\hline $\mathrm{MgO}$ & 13.25 & 9.71 & 6.55 & 5.44 & 0.83 & 0.22 & 0.34 & 0.21 \\
\hline $\mathrm{CaO}$ & 14.45 & 21.28 & 26.24 & 27.99 & 49.29 & 51.93 & 51.29 & 36.58 \\
\hline $\mathrm{BaO}$ & 0.13 & 0.72 & 0.09 & 0.13 & 0.26 & 0.29 & 0.35 & 4.55 \\
\hline $\mathrm{SrO}$ & 0.14 & 0.69 & 0.49 & 0.86 & $>1.18$ & $>1.18$ & $>1.18$ & $>1.18$ \\
\hline $\mathrm{Na}_{2} \mathrm{O}$ & 3.55 & 4.75 & 2.21 & 0.55 & 0.10 & 0.04 & 0.01 & $<0.01$ \\
\hline $\mathrm{K}_{2} \mathrm{O}$ & 1.76 & 1.60 & 0.80 & 0.28 & 0.10 & 0.02 & 0.01 & 0.03 \\
\hline $\mathrm{TiO}_{2}$ & 1.06 & 0.75 & 0.85 & 1.34 & 0.08 & 0.07 & 0.03 & 0.01 \\
\hline $\mathrm{P}_{2} \mathrm{O}_{5}$ & 0.42 & 0.91 & 6.75 & 4.56 & 4.95 & 2.82 & 2.85 & 0.11 \\
\hline LOI & 4.82 & 17.39 & 6.79 & 13.69 & 34.91 & 38.41 & 38.77 & 30.55 \\
\hline Total $^{\star \star}$ & 100.12 & 98.88 & 100.33 & 99.19 & 96.89 & 96.56 & 96.24 & 88.64 \\
\hline $\mathrm{BaO} / \mathrm{CaO}$ & 0.009 & 0.034 & 0.003 & 0.005 & 0.005 & 0.006 & 0.007 & 0.124 \\
\hline $\mathrm{SrO} / \mathrm{CaO}$ & 0.01 & 0.03 & 0.02 & 0.03 & & & & \\
\hline \multicolumn{9}{|c|}{ Trace elements (ppm) } \\
\hline V & 207 & 149 & 244 & 517 & 50 & 50 & 36 & 36 \\
\hline $\mathrm{Ba}$ & 1183 & 6442 & 783 & 1119 & 2349 & 2605 & 3093 & 40,720 \\
\hline $\mathrm{Sr}$ & 1180 & 5804 & 4266 & 7242 & $>10,000$ & $>10,000$ & $>10,000$ & $>10,000$ \\
\hline $\mathrm{Zr}$ & 118 & 68 & 84 & 92 & 28 & 4 & 10 & $<2$ \\
\hline $\mathrm{Cr}$ & 780 & 510 & 30 & $<20$ & $<20$ & $<20$ & $<21$ & $<20$ \\
\hline $\mathrm{Ni}$ & 310 & 220 & 30 & $<20$ & $<20$ & $<20$ & $<21$ & $<20$ \\
\hline $\mathrm{Cu}$ & 100 & 50 & 50 & 20 & 10 & 20 & 30 & $<10$ \\
\hline $\mathrm{Zn}$ & 60 & 90 & 145 & 340 & $<30$ & 30 & $<31$ & $<30$ \\
\hline $\mathrm{Nb}$ & 51 & 67 & 199 & 43 & 38 & 30 & 35 & 13 \\
\hline $\mathrm{Pb}$ & 6 & 26 & 13 & 47 & 12 & 15 & 12 & 138 \\
\hline Th & 20 & 42 & 180 & 64 & 130 & 50 & 112 & 270 \\
\hline La & 52 & 386 & 759 & 632 & 933 & 671 & 861 & $>2000$ \\
\hline $\mathrm{Ce}$ & 100 & 554 & 1445 & 1070 & 1620 & 1090 & 1440 & $>3000$ \\
\hline $\operatorname{Pr}$ & 11 & 47 & 148 & 100 & 153 & 97 & 133 & 375 \\
\hline $\mathrm{Nd}$ & 42 & 130 & 467 & 297 & 445 & 276 & 382 & 1140 \\
\hline Sm & 7 & 14 & 58 & 32 & 43 & 26 & 37 & 115 \\
\hline $\mathrm{Eu}$ & 2 & 4 & 16 & 8 & 10 & 6 & 9 & 26 \\
\hline $\mathrm{Gd}$ & 5 & 8 & 34 & 15 & 19 & 12 & 16 & 47 \\
\hline $\mathrm{Tb}$ & 1 & 1 & 4 & 2 & 2 & 1 & 2 & 4 \\
\hline Dy & 4 & 6 & 24 & 8 & 9 & 6 & 8 & 21 \\
\hline Ho & 1 & 1 & 4 & 1 & 1 & 1 & 1 & 4 \\
\hline $\mathrm{Er}$ & 2 & 3 & 12 & 4 & 4 & 3 & 4 & 11 \\
\hline $\mathrm{Tm}$ & $<1$ & $<1$ & 2 & $<1$ & $<1$ & $<1$ & 1 & 2 \\
\hline $\mathrm{Yb}$ & 1 & 2 & 9 & 3 & 2 & 2 & 3 & 12 \\
\hline Lu & $<1$ & $<1$ & 1 & $<1$ & $<1$ & $<1$ & $<1$ & 2 \\
\hline Y & 20 & 33 & 113 & 40 & 43 & 30 & 46 & 130 \\
\hline$\Sigma L R E E$ & 211 & 1131 & 2877 & 2131 & 3194 & 2160 & 2852 & $>6630$ \\
\hline$\Sigma H R E E$ & 15 & 25 & 106 & 41 & 48 & 30 & 43 & 128 \\
\hline
\end{tabular}

${ }^{\star} \mathrm{OKC} 4$ is a mafic dyke with OKC4m = OKC4 dyke margin and OKC4c = OKC4 dyke core. $L R E E=\mathrm{La}$ to $\mathrm{Sm}, H R E E=\mathrm{Eu}$ to $\mathrm{Lu}+\mathrm{Y} . \mathrm{Ge}, \mathrm{Sn}, \mathrm{In}, \mathrm{Ag}, \mathrm{Ti}, \mathrm{Cs}$ and $\mathrm{Bi}$ are $<2 \mathrm{ppm}$; Sb, Be, Hg, Ta and $\mathrm{U}$ are $<10 \mathrm{ppm}$ and $\mathrm{Ga}, \mathrm{As}, \mathrm{W}, \mathrm{Sc}, \mathrm{Rb}, \mathrm{Mo}$ and $\mathrm{Co}$ are $<60 \mathrm{ppm}$. BaO and SrO were calculated from the trace-element values.

${ }^{\star *}$ Total minus $(\mathrm{BaO}+\mathrm{SrO})$

bearing carbonatites (OKA5 and OKA1) and pegmatitic calcite carbonatites (OKC17, 18, 19) have the same suite of stage 3 hydrothermal alteration phases and similar REE patterns (Fig. 10; Table 1). The absence of Eu and Ce anomalies from all samples are distinctive (Figs 7, 10). We infer that the most altered carbonatites accumulated trace elements through growth of secondary phases, but these might well have been released from nearby ongoing alteration (Fig. 11).

An alternative hypothesis, which merits consideration, is that these enrichments are a residual effect due to net dissolution of calcite during stage 3. However, the manner in which hydrothermal calcite pseudomorphs magmatic calcite in the sample suite, and the lack of comparable enrichment in elements such as $\mathrm{Al}$ (Table 4), make this less likely.

In summary, stage 3 hydrothermal alteration resulted in modest changes in the composition of the calcite carbonatites, principally involving minor and trace elements which were initially present in magmatic calcite (Fig. 11). Although magmatic apatite has higher REE contents than magmatic calcite (by one order of magnitude), it is much less altered during hydrothermal alteration $(<10 \%)$, and it is considerably less abundant than calcite, hence it released a smaller amount of $R E E$ and the major part of the REE, together with $\mathrm{Ba}$ and $\mathrm{Sr}$ for hydrothermal minerals, was derived from magmatic calcite. Nevertheless, more altered samples are enriched in $\mathrm{Ba}, \mathrm{Sr}$ and $R E E$ relative to $\mathrm{Ca}$, reflecting the growth of the hydrothermal stage 3 minerals in which they are concentrated, and this suggests that these elements migrated to the areas of most intense alteration on a modest scale. In contrast, stage 4 hydrothermal alteration resulted in wholesale replacement of calcite by fluorite in the ore zones, with addition of $\mathrm{F}$ but removal of LREE, $\mathrm{Ba}$ and $\mathrm{Sr}$ as well as $\mathrm{CO}_{2}$. 


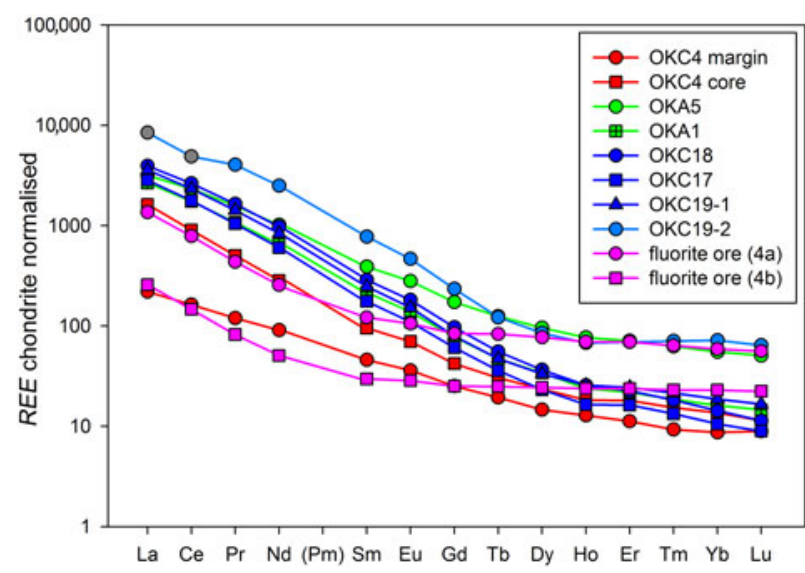

Fig. 10. Whole-rock data showing REE chondrite-normalised pattern of the Okorusu igneous rocks and fluorite body (McDonough and Sun, 1995). Note that the true Ce and La value of the intensely altered calcite carbonatite (OKC19-2) are higher than the recorded ones (grey) due to the instrument saturation (respectively $2000 \mathrm{ppm}$ and $3000 \mathrm{ppm}$ ). The symbol colours are independent from Fig. 7.

\section{Discussion}

Hydrothermal reworking has played an important role in determining the composition and mineralogy of the Okorusu carbonatite body. Hydrothermal changes are potentially significant for future exploitation of carbonatites for REE, because they dictate the REE mineralogy.

\section{Hydrothermal reworking of the calcite carbonatites}

We have argued above that the growth of parisite and other hydrothermal stage $3 \mathrm{a}$ phases in the calcite carbonatites resulted from breakdown of magmatic minerals, mainly calcite, releasing $R E E, \mathrm{Ba}$ and $\mathrm{Sr}$. While there is a qualitative match between the elements released from magmatic minerals and those taken up in stage 3 hydrothermal phases, the most altered samples show some enrichment, implying redistribution on a larger scale than the outcrops sampled (e.g. Fig. $3 b$ ). In particular, remobilisation

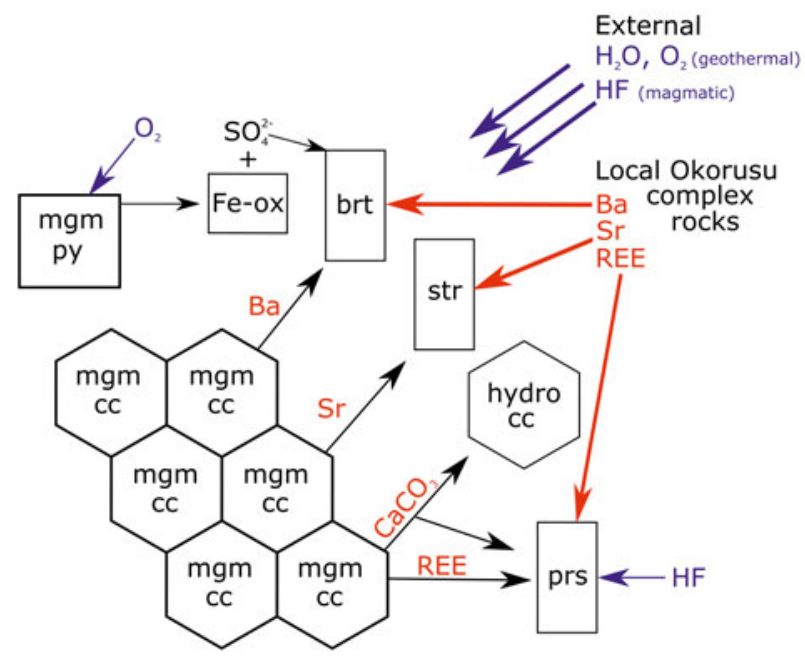

Fig. 11. Schematic presentation of the formation of the main hydrothermal assemblage observed in the altered Okorusu calcite carbonatites. Abbreviations: Fe-ox unidentified Fe hydroxide; cc - calcite; mgm - magmatic; hydro - hydrothermal; str - strontianite; prs - parisite; py - pyrite; brt - baryte. gave rise to a greater local $L R E E$ enrichment in the most intensely altered calcite carbonatite (OKC19-2) reflecting abundant stage 3 parisite mineralisation (Figs $4 k, 10$ ). The most intense hydrothermal alteration of the pegmatitic calcite carbonatite pod is close to the contact with the country rock, which may reflect enhanced fluid flow at the margin of the carbonatite body (Fig. 3b).

Local $L R E E$ enrichment in the intensely altered calcite carbonatite is accompanied by accumulation of $\mathrm{Ba}$ and $\mathrm{Sr}$, mainly as sulfates (Table 4). These are a key feature of stage 3 hydrothermal alteration at Okorusu. As baryte and celestine are nearly insoluble (Blount, 1977; Monnin, 1999), we infer that the Ba and $\mathrm{Sr}$ released from the breakdown of magmatic calcite and apatite were fixed by interaction with sulfate. A small percentage of magmatic pyrite $(<5 \%)$ was present in the calcite carbonatites initially, but is now partially altered to Fe hydroxides (Fig $4 g$ ) and so the reaction of pyrite with an introduced hydrothermal fluid is a probable source of local sulfate (Fig. 11).

The stage 3 fluid is inferred to have been oxidising because of the production of sulfate and the association of $\mathrm{Fe}$ hydroxides with the stage $3 \mathrm{~b}$ assemblages, however it was not sufficiently oxidising for Ce to be fractionated from the rest of the $R E E$ as $\mathrm{Ce}^{4+}$, as described in a similar setting by Anenburg et al. (2018). Assuming that all the $\mathrm{Ba}$ and $\mathrm{Sr}$ in the intensely altered calcite carbonatite (OKC19-2) are present in sulfate minerals, $\sim 13,000 \mathrm{ppm}$ of sulfur was needed to fix them. Oxidation of $3 \%$ modal pyrite, a typical level for the magmatic calcite carbonatites, will release around $16,000 \mathrm{ppm}$ sulfur as sulfate and so it is likely that sufficient sulfur is available in situ to fix the elevated Ba and $\mathrm{Sr}$ levels present in this sample.

There was probably an excess of $\mathrm{Ba}$ and $\mathrm{Sr}$ available, as they also form carbonate minerals, and in this case sulfate would not have been available in solution to enhance REE mobility (Migdisov and Williams-Jones, 2008).

\section{Conditions of REE mineralisation and hydrothermal reworking}

By analogy to experimental work on carbonatite systems by Weidendorfer et al. (2017) it is likely that the temperature of the magmatic stage of the Okorusu carbonatites was between $700^{\circ} \mathrm{C}$ and $1050^{\circ} \mathrm{C}$, although late-magmatic stage 2 crystallisation may have been somewhat cooler. Bühn et al. (2002) estimated that stage 4 alteration and fluorite growth took place at $150^{\circ} \mathrm{C} \pm 30^{\circ} \mathrm{C}$ from fluid-inclusion studies. Stage 3 and stage 4 hydrothermal alterations result in a similar hydrothermal mineral suite, although stage 4 is dominated by fluorite. In particular, calcite is present coexisting with dolomite in both stage 3 and stage 4 . The Mg content of calcite coexisting with dolomite is the basis for the calcite-dolomite solvus geothermometer calibrated by Anovitz and Essene (1987). In practice, the Mg content of stage $3 \mathrm{a}$ and stage 4 calcite is too low $\left(X_{\mathrm{Mg}}<0.001\right.$, Table 2) to apply this geothermometer except to give an upper temperature limit. The data indicate that both stages 3 and 4 developed at temperatures $<200^{\circ} \mathrm{C}$, in agreement with the earlier fluid-inclusion results.

\section{The relation between carbonatite evolution and hydrothermal reworking}

High-temperature hydrothermal activity commonly affects the rocks around carbonatite complexes, notably through the formation of fenites (Zharikov et al., 2007, Elliott et al., 2018), and so it is reasonable to ask if such magmatic fluids played a role in the 
hydrothermal alteration described here. Carbonatite melts are low viscosity (Jones et al., 2013) and rich in chloride salts and volatiles, predominantly $\mathrm{CO}_{2}$ and $\mathrm{H}_{2} \mathrm{O}$ (Mitchell, 2005; Rankin 2005). Salts and volatiles which are not retained in the carbonatite rocks give rise to fenitising fluid (Elliott et al., 2018). A minimum fenitisation temperature of $500^{\circ} \mathrm{C} \pm 30^{\circ} \mathrm{C}$ is indicated by experimental work (Zaraiskii, 1989). The upper temperature limit of fenites in natural systems is $>700^{\circ} \mathrm{C}$, measured at Amba Dongar (Williams-jones and Palmer, 2002). These are very different from the conditions of the hydrothermal alteration observed at Okorusu (Table 1), which indicate a distinct break between magmatic and hydrothermal conditions. In the absence of evidence of high- $T$ alteration in the rocks studied it unlikely that late-stage magmatic fluids were the only source responsible (c.f. Trofanenko et al., 2016). Furthermore, the fluid inclusions hosted in the fluorite lack a $\mathrm{CO}_{2}$ component and show low salinities (Bühn et al., 2002), unlike carbonatite fluid inclusions observed in other carbonatite bodies (e.g. Shu and Liu, 2019; Zheng and Liu, 2019; Rankin, 2005). Instead, the alteration observed is consistent with a maximum temperature of $200^{\circ} \mathrm{C}$ and the oxidising character of the hydrothermal fluid is suggestive of a geothermal system involving surface waters, although a magmatic origin for the added $\mathrm{F}$ seems very likely. A link between geothermal systems and hydrothermal mineralisation is documented extensively from many settings, with water of meteoric origin interacting with components derived from magmatic fluids and gases to produce a wide range of epithermal ores (e.g. White, 1981; Krupp and Seward, 1987). In this example, the development of hydrothermal massive fluorite points to continued magmatic vapour contributions to the geothermal fluid system down to low temperatures (Bühn et al., 2002, 2003).

\section{Conclusions}

The REE-rich carbonatites at Okorusu are originally of magmatic origin, but hydrothermal reworking has served to redistribute the $R E E$ into new minerals. Three alteration stages redistributed the $R E E$ at Okorusu. Stage 2 mineral growth is late magmatic and results in minor growth of $R E E$-depleted apatites after magmatic (stage 1) apatite. Stage 2 apatites exhibit lower REE contents than the stage 1 grains across the full lanthanide series (Fig. 7) but were accompanied by cogenetic parisite. Stages 3 and 4 are two distinct low-temperature hydrothermal events. Stage 3 involves partial breakdown of apatite and extensive recrystallisation of more abundant, trace-element-rich magmatic calcite, to purer hydrothermal calcite. Elements released from stage 1 magmatic minerals during alteration precipitated as parisite, baryte and celestine with lesser amounts of strontianite, witherite and other minor phases. Overall, stage 3 alteration is widespread in the different carbonatite pods and dykes, and is dominated by redistribution of $R E E$ without significant change in the bulk-rock composition. Nevertheless, there is evidence of enrichment in $\mathrm{Sr}, \mathrm{Ba}$ and $R E E$ during alteration in the most altered calcite carbonatites (Fig. 11). In contrast, stage 4 alteration resulted in widespread replacement of calcite carbonatite bodies (including those affected by stage 2 and stage 3 alteration) and country rock marbles by fluorite, and is accompanied by much more extensive metasomatic change than stage 3. Fluorite ore is low in $\mathrm{Ba}, \mathrm{Sr}$ and REE irrespective of precursor lithology and only the earliest fluorite, type $4 \mathrm{a}$, has associated parisite. The REE profiles of minerals from all alteration stages are close to that of the main REE-bearing magmatic phases (Fig. 7). Likewise, the REE bulk rock patterns of the different rocks (from mafic to fluorite ore) are comparable (Fig. 10). This suggests that the REE-bearing minerals developed in stages 2, 3 and 4 formed by redistribution of the REE from stage 1 magmatic minerals without a major external source of REE (Fig. 11).

Stage 3 alteration is responsible for the most abundant $R E E$ mineralisation at Okorusu, with $R E E$ derived from magmatic phases being concentrated into hydrothermal parisite. It developed at a temperature $<200^{\circ} \mathrm{C}$ and the associated baryte and celestine indicate an oxidising hydrothermal fluid, with sulfate probably derived from oxidation of magmatic pyrite. The most altered calcite carbonatite (OKC19-2) appears to have been enriched in $\mathrm{Ba}, \mathrm{Sr}$ and $R E E$ during the alteration.

The stage 3 and stage 4 hydrothermal alteration at Okorusu developed under low temperature, mildly oxidising conditions typically associated with geothermal systems. It is likely that surface-derived waters played an important role, but the extensive development of fluorite in stage 4 is indicative of an important contribution of F-rich fluid, probably of magmatic origin (Bühn et al., 2002, 2003).

Although Okorusu does not have economic potential for REE at present, this study demonstrates that hydrothermal alteration can serve to concentrate REE, forming hydrothermal REE minerals. The hydrothermal alteration of the main magmatic gangue mineral at Okorusu (calcite) has proven to be able to concentrate a significant amount of REE to form parisite-rich areas. Small amounts of hydrothermal alterations are sufficient to facilitate recrystallisation and the accompanying concentration of trace and minor elements into their own discrete secondary minerals, but more extensive alteration appears to be necessary to achieve significant overall enrichment.

Supplementary material. To view supplementary material for this article, please visit https://doi.org/10.1180/mgm.2019.54

Acknowledgements. We would like to thank Richard Walshaw and Duncan Hedges for help with the SEM imaging and the EMPA analyses at the University of Leeds. Ed Loye (University of Exeter) for organising access to Okorusu mine and Pedro and Boni for guiding us in the field at Okorusu. Rainer Ellmies (Gecko Namibia) kindly gave permission for the reproduction of the 3D mine model in Fig. 2. The manuscript was greatly improved by the contributions of three anonymous referees, while an earlier version benefitted from the perceptive comments of Dr. Chakhmouradian and Dr. Jindrich Kynicky. This work was supported by the NERC SoS: RARE project (NE/M01147X/1).

\section{References}

Alderton D.H.M., Pearce J.A. and Potts P.J. (1980) Rare earth element mobility during granite alteration: evidence from the southwest England. Earth and Planetary Science Letters, 49, 149-165.

Anenburg M. and Mavrogenes J.A. (2018) Carbonatitic versus hydrothermal origin for fluorapatite REE-Th deposits: Experimental study of REE transport and crustal "antiskarn" metasomatism. American Journal of Science, 318, 335-366.

Anenburg M., Burnham A.D. and Mavrogenes J.A. (2018) REE redistribution textures in altered fluorapatite: Symplectites, veins, and phosphate-silicatecarbonate assemblages from the Nolans bore P-REE-Th deposit, Northern Territory, Australia. The Canadian Mineralogist, 56, 331-354.

Anovitz L.M. and Essene E.J. (1987) Phase equilibria in the system $\mathrm{CaCO}_{3}-$ $\mathrm{MgCO}_{3}-\mathrm{FeCO}_{3}$. Journal of Petrology, 28, 389-414.

Banks D.A., Yardley B.W.D., Campbell A.R. and Jarvis K.E. (1994) REE composition of an aqueous magmatic fluid: A fluid inclusion study from the Capitan Pluton, New Mexico, U.S.A. Chemical Geology, 113, 259-272. 
Belousova E.A., Griffin W.L., O'Reilly S.Y., and Fisher N.I. (2002) Apatite as an indicator mineral for mineral exploration: trace-element compositions and their relationship to host rock type. Journal of Geochemical Exploration, 76, 45-69.

Blount C. (1977) Baryte solubilities and thermodynamic quantities up to $300^{\circ}$ $\mathrm{C}$ and 1400 bars. American Mineralogist, 62, 942-957.

Broom-Fendley S., Styles M.T., Appleton J.D., Gunn G. and Wall F. (2016) Evidence for dissolution-reprecipitation of apatite and preferential LREE mobility in carbonatite-derived late-stage hydrothermal processes. American Mineralogist, 101, 596-611.

Broom-Fendley S., Aoife B.E., Wall F., Gunn G. and Dawes W. (2017a) REE minerals at the Songwe Hill carbonatite, Malawi: HREE-enrichment in latestage apatite. Ore Geology Reviews, 81, 23-41.

Broom-Fendley S., Wall F., Spiro B. and Ullmann C.V. (2017b) Deducing the source and composition of rare earth mineralising fluids in carbonatites: insights from isotopic $\left(\mathrm{C}, \mathrm{O},{ }^{87} \mathrm{Sr} /{ }^{86} \mathrm{Sr}\right)$ data from Kangankunde, Malawi. Contributions to Mineralogy and Petrology, 172, 96.

Bühn B., Rankin A.H., Schneider J. and Dulski P. (2002) The nature of orthomagmatic, carbonatitic fluids precipitating $R E E$, $\mathrm{Sr}$-rich fluorite: fluid-inclusion evidence from the Okorusu fluorite deposit, Namibia. Chemical Geology, 186, 75-98.

Bühn B., Schneider J., Dulski P. and Rankin A.H. (2003) Fluid-rock interaction during progressive migration of carbonatitic fluids, derived from small-scale trace element and $\mathrm{Sr}, \mathrm{Pb}$ isotope distribution in hydrothermal fluorite. Geochimica et Cosmochimica Acta, 67, 4577-4595.

Chakhmouradian A.R. and Wall F. (2012) Rare earth elements: Minerals, mines, magnets (and more). Elements, 8, 333-340.

Chakhmouradian A.R. and Zaitsev A.N. (2012) Rare earth mineralization in igneous rocks: Sources and processes. Elements, 8, 347-353.

Chakhmouradian A.R., Reguir E.P. and Zaitsev A.N. (2016) Calcite and dolomite in intrusive carbonatites. I. Textural variations. Mineralogy and Petrology, 110, 333-360.

Chakhmouradian A.R., Reguir E.P., Zaitsev A.N., Couëslan C., Xu C., Kynický J., Mumin A.H. and Yang P. (2017) Apatite in carbonatitic rocks: Compositional variation, zoning, element partitioning and petrogenetic significance. Lithos, 275, 188-213.

Chebotarev D.A., Veksler I.V., Wohlgemuth-Ueberwasser C., Doroshkevich A.G., and Koch-Müller M. (2019) Experimental study of trace element distribution between calcite, fluorite and carbonatitic melt in the system $\mathrm{CaCO}_{3}+\mathrm{CaF}_{2}+$ $\mathrm{Na}_{2} \mathrm{CO}_{3} \pm \mathrm{Ca}_{3}\left(\mathrm{PO}_{4}\right)_{2}$ at $100 \mathrm{MPa}$. Contributions to Mineralogy and Petrology, 174, 1-13.

Elliott H.A.L., Wall F., Chakhmouradian A.R., Siegfried P.R., Dahlgren S., Weatherley S., Finch A.A., Marks M.A.W., Dowman E., and Deady E. (2018) Fenites associated with carbonatite complexes: A review. Ore Geology Reviews, 93, 38-59.

European Commission (2017) The European Economic and Social Committee and the Committee of the Regions on the 2017 List of Critical Raw Materials for the EU. Communication from the commission to the European parliament, the council. pp. 490.

Feng M., Xu C., Kynicky J., Zeng L. and Song W. (2016) Rare earth element enrichment in Palaeoproterozoic Fengzhen carbonatite from the North China block. International Geology Review, 58, 1940-1950.

Giebel R.J., Gauert C.D.K., Marks M.A.W., Costin G. and Markl G. (2017) Multi-stage formation of REE minerals in the Palabora Carbonatite Complex, South Africa. American Mineralogist, 102, 1218-1233.

Glover E.D. and Sippel R.F. (1962) Experimental pseudomorphs: Replacement of calcite by fluorite. American Mineralogist, 47, 1156-1165.

Gysi A.P. and Williams-Jones A. (2013) Hydrothermal mobilization of pegmatite-hosted $R E E$ and $\mathrm{Zr}$ at Strange Lake, Canada: a reaction path model. Geochimica et Cosmochimica Acta, 122, 324-352.

Hagni R.D. and Shivdasan P.A. (2000) Characterizing megascopic textures in fluorospar ores at Okorusu mine. JOM, 52, https://doi.org/10.1007/s11837000-0124-y

Hagni R.D. and Shivdasan P.A. (2001) Application of cathodoluminescence microscopy to the study of carbonatite-related fluorspar ores, host rock carbonatites and beneficiation products at Okorusu, Namibia. Minerals and Metallurgical Processing, 18, 203-208.
Harlov D.E., Förster H.J. and Schmidt C. (2003) High P-T experimental metasomatism of a fluorapatite with significant britholite and fluorellestadite components: implications for $L R E E$ mobility during granulite-facies metamorphism. Mineralogical Magazine, 67, 61-72.

Harlov D.E., Wirth R. and Förster H.J. (2005) An experimental study of dissolution-reprecipitation in fluorapatite: Fluid infiltration and the formation of monazite. Contributions to Mineralogy and Petrology, 150, 268-286.

Holtstam D. and Andersson U.B. (2007) The REE minerals of the Bastnäs-type deposits, South-Central Sweden. The Canadian Mineralogist, 45, 1073-1114.

Holtstam D., Andersson U.B., Broman C. and Mansfeld J. (2014) Origin of $R E E$ mineralization in the Bastnäs-type $\mathrm{Fe}-\mathrm{REE}-(\mathrm{Cu}-\mathrm{Mo}-\mathrm{bi}-\mathrm{Au})$ deposits, Bergslagen, Sweden. Mineralium Deposita, 49, 933-966.

Jones A.J., Genge M. and Carmody L. (2013) Carbonate melts and carbonatites. Pp. 289-322 in: Carbon in Earth (R.M. Hazen, A.P. Jones and J.A. Baross). Reviews in Mineralogy and Geochemistry, 75. Mineralogical Society of America and the Geochemical Society, Chantilly, Virginia, USA.

Kapustin I. (1980) Mineralogy of Carbonatites. Amerind Publishing Co., New Delhi.

Krupp R.E. and Seward T.M. (1987) The Rotokawa geothermal system, New Zealand: An active epithermal gold-depositing environment. Economic Geology, 82, 1109-1129.

Le Bas M.J. and Srivastava R.K. (1989) The mineralogy and geochemistry of the Mundwana carbonatite dykes, Sirohi District, Rajasthan, India. Journal of Mineralogy and Geochemistry, 160, 207-227.

Lewis A.J., Komninou A., Yardley B.W.D. and Palmer M.R. (1998) Rare earth element speciation in geothermal fluids from Yellowstone National Park, Wyoming, USA. Geochimica et Cosmochimica, 62, 657-663.

Linnen R.L., Samson I.M., Williams-Jones A.E. and Chakhmouradian A.R. (2014) Geochemistry of the rare-earth element, $\mathrm{Nb}, \mathrm{Ta}, \mathrm{Hf}$, and $\mathrm{Zr}$ deposits. Pp 543-569 in: Treatise on Geochemistry. Second Edition. Elsevier

McDonough W.F. and Sun S. (1995) The composition of the earth. Chemical Geology, 120, 223-253.

Migdisov A.A. and Williams-Jones A.E. (2008) A spectrophotometric study of $\mathrm{Nd}(\mathrm{III}), \mathrm{Sm}(\mathrm{III})$ and $\mathrm{Er}(\mathrm{III})$ complexation in sulfate-bearing solutions at elevated temperatures. Geochimica et Cosmochimica Acta, 72, 5291-5303.

Migdisov A., Williams-Jones A.E., Brugger J. and Caporuscio F.A. (2016) Hydrothermal transport, deposition, and fractionation of the REE: Experimental data and thermodynamic calculations. Chemical Geology, 439, 13-42.

Milner S.C., Le Roex A.P. and O'Connor J.M. (1995) Age of Mesozoic igneous rocks in northwestern Namibia, and their relationship to continental breakup. Journal of the Geological Society, 152, 97-104.

Mitchell R.H. (2005) Carbonatites and carbonatites and carbonatites. The Canadian Mineralogist, 43, 2049-2068.

Monnin C. (1999) A thermodynamic model for the solubility of barite and celestine in electrolyte solutions and seawater to $200^{\circ} \mathrm{C}$ and to $1 \mathrm{kbar}$. Chemical Geology, 153, 187-209.

Moore M., Chakhmouradian A.R., Mariano A.N. and Sidhu R. (2015) Evolution of rare-earth mineralization in the Bear Lodge carbonatite, Wyoming: Mineralogical and isotopic evidence. Ore Geology Reviews, 64, 499-521.

Nadoll P., Rehm M., Duschl F., Klemd R., Kraemer D., and Sośnicka M. (2018) REY and trace element chemistry of fluorite from Post-Variscan hydrothermal veins in Paleozoic units of the North German Basin. Geosciences, 8, 283-312.

Packwood R.H. and Brown J.D. (1981) A Gaussian expression to describe $\Phi(\rho z)$ curves for quantitative electron probe microanalysis. X-RAY Spectrometry, 10, 138-146.

Perry P. and Gysi A. (2018) Rare earth elements in mineral deposits: speciation in hydrothermal fluids and partitioning in calcite. Geofluids, 2018, 1-19.

Rankin A.H. (2005) Carbonatite-associated rare metal deposits - Composition and evolution of ore-forming fluids - The fluid inclusion evidence. Pp. 299-314 in: Rare-Element Geochemistry and Mineral Deposits (R.L. Linnen and I.M. Samson, editors). Short Course Notes 17, Geological Association of Canada, Quebec.

Reguir E.P., Chakhmouradian A.R., Pisiak L.H., Halden N.M., Yanng P., Xu C., Kynický J. and Couëslan C.G. (2012) Trace-element composition and 
zoning in clinopyroxene- and amphibole-group minerals: Implications for element partitioning and evolution of carbonatites. Lithos, 128-131, $27-45$.

Roedder E. (1973) Fluid inclusions from the fluorite deposits associated with carbonatite of Amber Dongar, India and Okorusu, South West Africa. Transaction of the Institution of Mining and Metallurgy, 82, 35-39.

Schreiber U.M., Milners S.C. and Goscombe B.G. (1977) Geological Map of Namibia: 1:250 000 Geological Series. Geological Survey of Namibia, Windhoek.

Shivdasan P. (2002) Petrology, Geochemistry, and Mineralogy of Pyroxene and Pegmatite Carbonatite and the Associated Fluorspar Deposit at Okorusu Alkaline Igneous Carbonatite Complex, Namibia. PhD dissertation, University of Missouri-Rolla, USA.

Shu X. and Liu Y. (2019) Fluid inclusion constraints on the hydrothermal evolution of the Dalucao Carbonatite-related REE deposit, Sichuan Province, China. Ore Geology Reviews, 107, 41-57.

Smith M.P., Henderson P. and Campbell L.S. (2000) Fractionation of the REE during hydrothermal processes: constraints from the Bayan Obo Fe-REE$\mathrm{Nb}$ deposit, Inner Mongolia, China. Geochimica et Cosmochimica Acta, 64, 3141-3160.

Smith M.P., Moore K., Finch A.A., Kynicky J. and Wall F. (2016) From mantle to critical zone, a review of large and giant sized deposits of the rare earth elements. Geoscience Frontiers, 7, 315-334.

Sturm R. (2002) PX-NOM - An interactive spreadsheet program for the computation of pyroxene analyses derived from the electron microprobe. Computers and Geosciences, 28, 473-483.

Trofanenko J., Williams-Jones A.E., Simandl G.J. and Migdisov A.A. (2016) The nature and origin of the REE mineralization in the Wicheeda carbonatite, British Columbia, Canada. Economic Geology, 111, 199-223.

U.S. Geological Survey (2018) Mineral Commodity Summaries 2018. U.S. Geological Survey, Reston, Virginia, USA.

Van Zijl P (1962) The Geology, Structure and Petrology of the Alkaline Intrusions of Kalkfeld and Okorusu and the Invaded Damara Rocks. PhD dissertation, University of Stellenbosch, South Africa.

Verplanck P.L., Mariano A.N. and Mariano A. (2016) Rare earth element ore geology of carbonatites. Pp. 5-32 in: Rare Earth and Critical Elements in
Ore Deposits (P.L. Verplanck and M.W. Hitzman, editors). Review of Economic Geology, 18. Society of Economic Geologists, Inc., Littleton, Colorado, USA.

Wall F. (2014) Rare earth elements. Pp. 312-340 in: Critical Metals Handbook (A. Gunn, editor). Wiley, New York.

Wall F., Niku-Paavola V.N., Storey C.M. and Axel J.T. (2008) Xenotime-(Y) from carbonatite dykes at Lofdal, Namibia: Unusually low LREE:HREE ratio in carbonatite, and the first dating of xenotime overgrowths on zircon. The Canadian Mineralogist, 46, 861-877.

Weidendorfer D., Schmidt M.W. and Mattsson H.B. (2017) A common origin of carbonatite magmas. Geology, 45, 507-510.

White D.E. (1981) Active geothermal systems and hydrothermal ore deposits. Economic Geology, 75, 392-423.

Williams-Jones A.E. and Palmer D.A.S. (2002) The evolution of aqueouscarbonic fluids in the Amba Dongar carbonatite, India: Implications for fenitisation. Chemical Geology, 185, 283-301.

Williams-Jones A.E., Migdisov A.A. and Samson I.M. (2012) Hydrothermal mobilisation of the rare earth elements - a tale of "ceria" and "yttria". Elements, 8, 13-42.

Zaitsev A.N., Wall F. and Le Bas M.J. (1998) REE-Sr-Ba minerals from the Khibina carbonatites, Kola Peninsula, Russia: their mineralogy, paragenesis and evolution. Mineralogical Magazine, 62, 225-250.

Zaitsev A., Demény A., Sindern S. and Wall F. (2002) Burbankite group minerals and their alteration in rare earth carbonatites: source of elements and fluids (evidence from C-O and Sr-Nd isotopic data). Lithos, 62, 15-33.

Zaraiskii G.P. (1989) Zonation and Conditions of Metasomatic Rocks Formation. Nauka Publishing, Moscow.

Zharikov V.A., Pertsev N.N., Rusinov V.L., Callegari E. and Fettes D.J. (2007) Metasomatism and metasomatic rocks. Recommendations by the IUGS Subcommision of the Systematics of Metamorphic Rocks. [available at https://www.bgs.ac.uk/scmr/products.html]

Zheng X. and Liu Y. (2019) Mechanisms of element precipitation in carbonatite-related rare-earth element deposits: Evidence from fluid inclusions in the Maoniuping deposit, Sichuan Province, southwestern China. Ore Geology Reviews, 107, 218-238. 